\title{
Explaining Underutilization of Tax Depreciation Deductions: Empirical Evidence from Norway
}

\author{
KARL OVE AARBU \\ Vesta Forsikring A/S, Folke Bernadottes vei 50, 5020 Bergen, Norway \\ JEFFREY K. MACKIE-MASON \\ Department of Economics, University of Michigan, Ann Arbor, MI, 48109-1092, USA
}

\author{
karl.ove.aarbu@vesta.no
}

jmm@umich. edu

\begin{abstract}
Many corporations do not claim all of their allowable tax depreciation deductions. Intuitively, this kind of behavior might seem odd. However we propose several possible explanations. First, we find strong evidence that firms facing current tax losses or carrying forward past losses underutilize depreciation in order to recover tax losses before they expire. Second, corporations with bad economic performance tend to underutilize their deductions, suggesting that corporations use costly "windowdressing" on their accounting measures. Third, we find support for the hypothesis that tax compliance costs discourage the utilization of accelerated depreciation, especially by small firms. We do not find much support for other hypotheses. For example, we find no evidence of substitution between tax depreciation and private debt due to competition between the benefits of private bank monitoring and the tax savings from using tax allowances to postpone tax payments, as suggested in earlier literature. We also study the effects of the uniform reporting accounting system (typical of many European countries) which can, under certain circumstances, constrain dividends. Forgoing some tax depreciation can loosen the dividend constraint, but the evidence does not support this motivation. Unusual access to extremely detailed individual firm tax return forms in Norway made our empirical analysis possible. In addition, the 1992 Norwegian tax reform provided a natural experiment for testing some of the hypotheses. We use the time-series and cross-sectional variation across Norwegian corporations in 1988, 1991, 1992 and 1993.
\end{abstract}

Keywords: corporate taxes, depreciation, reporting conventions

JEL Code: D21, H25

\section{Introduction}

Simple common sense tells us that, all else equal, a firm should prefer to claim depreciation deductions earlier rather than later: a year of postponement increases the present value of tax payments by the discount factor $(r /(1+r))$ times the tax rate times the difference between tax depreciation allowed and the depreciation actually claimed. However, many corporations do not fully utilize allowable tax depreciation. Kanniainen and Södersten (1994) refer to several studies that report underutilization in Sweden and Finland. Forsling (1998a) reports underutilization of both depreciation and other tax allowances in Sweden throughout 1979-1993. Askildsen and Fjærli (1989) find indirect evidence suggesting underutilization of tax depreciation by Norwegian corporations; Aarbu (1994) confirms underutilization in Norwegian firms with direct evidence. The Technical Committee on 
Table 1. Underutilization of tax depreciation in Norwegian firms. (Calculated by the authors from a sample of corporate tax returns prepared by Statistics Norway. Underutilization is calculated as total depreciation allowed minus the total depreciation claimed, divided by total depreciation claimed. Values are weighted to represent the population of firms. Sample size is rounded to nearest hundred.)

\begin{tabular}{lrrrr}
\hline Year & 1988 & 1991 & 1992 & 1993 \\
\hline Sample size & 1700 & 4400 & 4300 & 2400 \\
Mean percent underutilization & 10 & 21 & 8 & 9 \\
Percent of firms that do not use maximal tax depreciation & 39 & 44 & 25 & 20 \\
\hline
\end{tabular}

Business Taxation (1997) in Canada documents this fact for Canadian companies during 1985-1993. In Table 1 we summarize the underutilization of tax depreciation by Norwegian corporations in 1988, 1991, 1992 and 1993. ${ }^{1}$

Underutilization is substantial: about 10 percent of allowable depreciation is not deducted in each year, with a peak of 21 percent in the recession year of 1991 . Forsling (1998a) reports about 5\% average underutilization of depreciation, and 5-10\% underutilization of all allowances in Sweden over 1979-1993. In our Norwegian sample between 20 and 40 percent of firms do not fully utilize their allowable depreciation deductions. The significant changes after 1991 may be the result of the Norwegian tax reform that took effect in 1992, which thus provides us with a natural experiment. The underutilization is also quite large measured in absolute terms. The foregone deductions in 1991 were approximately 3 billion NOK, and around 1 billion NOK in each of the other years, which converts to about $\$ 100$ to $\$ 330$ million US. The amounts represent about $0.1-0.5 \%$ of Norwegian GDP.

These facts are quite surprising. Firms in Norway are prepaying between 280 million and 1.5 billion NOK in taxes (using 1992 tax rates), foregoing one year or more of interest on that amount. Another interpretation makes the point more plainly: when firms underutilize depreciation they are foregoing zero-interest loans from the government. We find that about 12.5 percent of the firms in 1991 (about 5 percent in 1988 and 3 percent in other years) forego zero-interest loans, i.e. underutilize depreciation allowances, and at the same time increase private long-term debt. ${ }^{2}$ Thus, our research fits squarely in the literature on corporate financial behavior, with the following question: why do firms forego substantial interest-free loans from the government? ${ }^{3}$

We can illustrate the potential significance of underutilization through a standard cost of capital calculation for a $\$ 1$ asset that follows declining balance (DB) depreciation. If the DB rate is $30 \%$ and the interest rate is $10 \%$ then the present value of the allowances will be $30 \% /(30 \%+10 \%)$, or $\$ 0.75$. If the firm chooses to depreciate at $20 \%$ instead of $30 \%$, all else equal, the value of the depreciation allowance is $\$ 0.67$, and the cost of the asset is increased by $8 \%$.

We consider several possible explanations for this behavior, and then test the hypotheses on firm-level tax return data from Norway. Our findings suggest that several factors play a role:

- Tax loss carry forwards compete with depreciation deductions. Loss carryforwards expire, while depreciation can be postponed forever. 
- Corporations forego depreciation deductions to apply "windowdressing" to their accounting earnings when they have losses, low profits or other signs of economic distress.

- Tax system accounting compliance costs from maintaining different tax and financial reporting accounts provide a significant incentive to forego depreciation savings.

We also investigate two other hypotheses. First, the uniform reporting accounting system used in many OECD countries, including Norway before 1992, imposes a constraint on dividend payments that can be relaxed by under-utilizing depreciation deductions. Thus to the extent that paying dividends is valuable to the firm - as suggested by various signaling stories (and the fact that dividends are paid in countries in which they are tax disfavored) a firm that is constrained may forego accelerated depreciation in order to increase dividend payments. ${ }^{4}$ Our results provide little support for the economic importance of the dividend constraint, though.

Kanniainen and Södersten (1994) suggest another hypothesis: that underutilization may lower the costs of monitoring the firm's managers. This story focuses on the financial trade-off between tax debt and private debt, and assumes that the firm may wish to forego some tax debt if private debt providers (primarily banks) provide monitoring services in exchange for the higher interest rate on private debt compared to tax debt. We do not find support for this hypothesis.

Our empirical analysis is based on firm level data from 1988, 1991, 1992 and 1993. There are several advantages to our data. First, they cover two years before the tax reform and two years after, so we can test whether the behavior changed due to the tax reform. The tax reform changed certain important accounting rules, creating a significant natural experiment for testing our hypotheses. Our data set includes both small, closely-held corporations and large corporations, allowing us to test whether there are significant differences in behavior between different size corporations. Third, we have extremely detailed firm-level tax return data, of a quality that usually is unavailable to researchers.

In the next section we describe key features of the corporate tax system imposed on the firms in our sample. In Section 3 we discuss various theoretical explanations for tax depreciation underutilization. We discuss our data, econometric specification and method in Section 4. We provide our empirical results in Section 5, and in Section 6 offer concluding observations.

\section{The Norwegian Corporate Tax System}

\subsection{Before the 1992 Tax Reform}

In this section we derive the accounting relationship between tax depreciation, dividends, tax payments and book equity. Before its 1992 tax reform, Norway required uniform reporting, as do many OECD countries. Uniform reporting requires reconciliation between the tax and the accounting measures. ${ }^{5}$ We present the implications of this requirement below. ${ }^{6}$

Norwegian corporate tax law permits a corporation to pay dividends out of current profit plus free equity (accumulated retained earnings). In Appendix A we derive the following accounting identity: 


$$
\Pi-d^{\mathrm{B}}-r B-\left(d^{\mathrm{T}}-d^{\mathrm{B}}\right)-F-T+\Omega=D+R+(\Delta \Omega+\Omega)
$$

where $\Pi$ is operating profits, $d^{\mathrm{B}}$ is book depreciation, $d^{\mathrm{T}}$ is tax depreciation (and thus $\left(d^{\mathrm{T}}-d^{\mathrm{B}}\right)$ is accelerated depreciation), $F$ is tax-deferred fund allocations, $T$ is corporate tax and $r B$ is net interest cost where $r$ is the interest rate and $B$ is the net debt, $R$ is the allocation to the reserve fund, $D$ is dividends and $\Omega$ is the firm's free equity. ${ }^{7} \mathrm{We}$ assume that $D \geq 0$. The residual $\Delta \Omega$ can be positive or negative depending on the current profit. Under normal circumstances book depreciation and tax depreciation will follow different paths. ${ }^{8}$ However, under uniform reporting firms must reconcile their reported accounting profits so that they are equal to taxable profits. As a consequence, profits after tax and accumulated retentions of such (which together comprise potential dividends) are a function of claimed tax depreciation (and not of book depreciation). ${ }^{9}$ In order to discuss this identity in more detail we define the fund allocation $F$ as

$$
F=\varphi \max \left(0, \Pi-d^{\mathrm{B}}-r B-\left(d^{\mathrm{T}}-d^{\mathrm{B}}\right)-\Psi\right),
$$

where $\varphi$ is the consolidation fund allocation rate, 23 percent in 1991, and $\Psi$ denotes tax loss carryforwards.

Furthermore, the tax base can be specified as

$$
\begin{aligned}
T= & \eta\left(\Pi-d^{\mathrm{B}}-r B-\left(d^{\mathrm{T}}-d^{\mathrm{B}}\right)-F-\Psi\right) \\
& +\kappa\left(\Pi-d^{\mathrm{B}}-r B-\left(d^{\mathrm{T}}-d^{\mathrm{B}}\right)-F-\Psi-\max \left[0, D^{*}\right]\right),
\end{aligned}
$$

where $\eta$ is the municipal tax rate and $\kappa$ the national tax rate. The variable $D^{*}$ is the maximum possible dividends and is given as

$$
D^{*}=\min \left[D, \Pi-d^{\mathrm{B}}-r B-\left(d^{\mathrm{T}}-d^{\mathrm{B}}\right)-F-\Psi\right] .
$$

If we insert these definitions into (1) and add $d^{\max }$ on each side we get, after some manipulation,

$$
\begin{gathered}
d^{\max }-d \equiv d^{\max }+r B-\Pi-\frac{1}{(1-\varphi)(1-u)}[(\varphi+(1-\varphi) u) \Psi-D(1-\kappa) \\
-(\Delta \Omega+\Omega)-R]
\end{gathered}
$$

where $u=\eta+\kappa$. Equation (2) summarizes the accounting constraint dependence between underutilization of tax depreciation and different sources and uses of income. For example, an increase in dividends $(D)$ or book equity $(\Delta \Omega)$ can be achieved by higher underutilization.

In equation (2) we have assumed that the firm is paying positive taxes, and in this case higher loss carryforwards $(\psi)$ reduce the need to underutilize depreciation to relax the constraint. When $T>0$, higher $\psi$ means lower $T$ paid and lower consolidation fund allocations, both of which leave more slack with which to pay dividends without resorting to higher underutilization. 


\subsection{The Corporate Tax System after 1992}

The 1992 tax reform changed the Norwegian corporate tax system radically. For our purpose, the most important change was to replace uniform reporting with separate reporting. ${ }^{10}$ The result is that the firm's choice of tax depreciation does not directly affect the dividend constraint. This change offers a natural experiment to test the importance of the dividend constraint as an explanation of the underutilization of depreciation deductions.

Before the reform the difference between tax and accounting depreciation was deducted from accounting profit, and registered as an increase in long-term debt; after the reform accounting profit is not affected by the amount of tax depreciation claimed. That is, the deferred tax due to accelerated depreciation is deducted from current profits, which cancels out the effect of tax depreciation on the dividend constraint. The effect of this is to change the accounting identity (1) to:

$$
(1-\tau)\left(\Pi-d^{\mathrm{B}}-r B\right)+\tau \Psi+\Omega=D+R+(\Delta \Omega+\Omega) .
$$

The switch to the separate reporting convention will normally loosen the dividend constraint, because book depreciation is normally lower than tax depreciation.

However the overall tax reform could have either loosened or tightened the dividend constraint, depending on the firm's circumstances. If we insert the expressions for taxes and consolidation fund in equation (1), and then take the difference between the left-hand sides in equations (1) and (3), we obtain as the difference between the accounting identity constraints $^{11}$

$$
\left(\Pi-d^{\mathrm{B}}-r B\right)(1-\tau-(1-\varphi)(1-u))+(1-\varphi)(1-u)\left(d^{\mathrm{T}}-d^{\mathrm{B}}\right) .
$$

If this expression is positive, the dividend constraint is less binding after the 1992-reform. However, the sign of the last term is ambiguous. In a firm with positive net investments, tax depreciation will normally be larger than book depreciation, and the last term is positive. For a firm with negative net investments the opposite may be true and the constraint may be more binding. Since the Norwegian economy began a sharp recovery in 1992 the reform loosened the constraint for most firms.

\section{Toward a Theory of Tax Overpayment}

How large is the amount the corporation will lose if it underutilizes depreciation allowances? To present the idea simply we will only look at one investment at time zero. Let $K$ be the capital investment in the starting period, $\delta$ be the book (and economic) depreciation rate, $\rho$ be the maximal tax depreciation rate, and $u$ be the tax rate. Then present value of tax depreciation is:

$$
u \int_{0}^{\infty} \rho K \mathrm{e}^{-(\rho+r) t} \mathrm{~d} t=u \frac{\rho}{\rho+r} K .
$$

The present value when the corporation chooses to use book depreciation is: 


$$
u \int_{0}^{\infty} \delta K \mathrm{e}^{-(\delta+r) t} \mathrm{~d} t=u \frac{\delta}{\delta+r} K .
$$

The loss from underutilizing the extra tax depreciation allowance is the difference between the present values:

$$
u \frac{r(\rho-\delta)}{(r+\rho)(r+\delta)} K .
$$

This loss increases when the capital investment $(K)$ is high, or the interest rate is high. Thus, we should expect lower underutilization when the depreciation base or the interest rate is high.

But why should there be any underutilization? We believe that there may be several rational causes. In the following subsections we present several such hypotheses. ${ }^{12} \mathrm{We}$ also identify their testable implications in preparation for our empirical investigation.

\subsection{The Dividend Constraint}

In our description of the pre-reform tax system we showed that a corporation can relax the legal constraint on dividend distribution by decreasing the use of accelerated depreciation. After the tax reform tax depreciation does not enter the constraint directly, but if the firm for other reasons claims book depreciation as a function of tax depreciation then the choice of tax depreciation will still affect the maximum permitted dividend distribution. ${ }^{13}$

Various authors propose signaling theories to explain why corporations might pay dividends even when they are tax disfavored. The theories predict both that there is an optimal positive level of dividends, and that there is an advantage to keeping dividends constant or increasing over time. These objectives may be thwarted by the legal dividend constraint, especially when a firm experiences low earnings. Claiming lower tax depreciation can offset low earnings in calculating the dividend constraint. Since the signaling stories follow from information asymmetries between corporate managers and the shareholders, one testable implication is that the dividend constraint should be less important for small corporations and corporations not traded publicly.

\subsection{Competition with Tax Loss Carryforwards}

Just as we characterize underutilized depreciation as a foregone zero-interest loan from the government, we can view tax loss carryforwards as a zero-interest (involuntary!) loan from a firm to the government. When a firm reports a tax loss, the government does not return the negative tax liability immediately. Instead, the government retains the funds (without interest) until a future year in which the firm may reduce positive taxable income by the amount of the loss carryforward. Since underutilized depreciation and tax loss carryforwards (TLCF) are both zero-interest loans between firm and government (in opposite directions) we might expect a firm's TLCF position to affect the firm's depreciation strategy. ${ }^{14}$ 
There are two significant differences between the "loan terms" on tax losses and underutilized depreciation that are relevant for the effect TLCF will have on depreciation strategy. Foregone depreciation can be recovered with certainty, for the most part, by making depreciation deductions in the future. However, since a firm cannot claim more tax depreciation than corresponds to the maximum depreciation rate, a $\$ 1$ reduction in depreciation claimed in year $t$ cannot be recovered until the final year of the asset's life. Thus, underutilized depreciation is a term loan with no early call provision.

Tax loss carryforwards, by contrast, can be recovered in any year in which the firm has positive taxable income: there is an annual call provision. However, there is also an expiration date: losses carried forward more than 10 years (in Norway) expire and the loan can no longer be recovered. ${ }^{15}$

Now, consider the interaction: Suppose a firm has positive TLCF and is considering whether to underutilize depreciation. Deducting $\$ 1$ more of its currently allowable depreciation will lower the firm's taxable income by $\$ 1$. However, claiming $\$ 1$ of its outstanding loss carryforwards would have exactly the same effect on current income. Should the firm claim the depreciation, or instead underutilize and claim the TLCF?

If we consider just the different call provisions of the two tax loans, ignoring the TLCF expiration, then claiming current depreciation dominates claiming TLCF. Underutilized depreciation cannot be recovered for (possibly many) years, while unclaimed TLCFs can be claimed next year if there is positive income. ${ }^{16}$ However, TLCFs expire and depreciation does not. The firm loses the interest on deferred depreciation, but may lose the principle on TLCFs if carried too long. Suppose TLCFs expired after one year: then the firm would always first recover TLCFs, claiming depreciation only after all TLCFs were utilized.

Thus, there is some incentive to substitute between TLCFs and depreciation deductions. The optimal utilization of TLCFs and depreciation allowances will tend to lie between the two extremes of "all depreciation" and "all TLCF" depending on parameters such as the interest rate, the depreciable life of the asset, the vintage profile of the outstanding TLCFs, and the expected path of future earnings.

We illustrate this substitution in Figure 1. For a particular project, we show the potential loss or gain from claiming full depreciation (rather than underutilizing to permit earlier recovery of TLCFs) as a function of the firm's profit rate on the initial investment. The horizontal axis shows alternative long-term gross profit rates. For this example we assume a $5 \%$ rate of economic depreciation, a $30 \%$ tax depreciation rate, ${ }^{17}$ a $50 \%$ tax rate, a $3 \%$ discount rate, a 10-year loss carryforward period and a 30-year investment life. For simplicity, we assume that book depreciation equals economic depreciation. On this basis we calculate the present value of the tax difference between a case where the firm claims full depreciation regardless of the profit rate, and a case where it claims only as much depreciation as it can without incurring tax losses. The tax difference (in present value terms) between these two cases is expressed in percent of the initial investment and is depicted in Figure 1. When the long-term profit rate is zero, the choice of depreciation and loss strategy is irrelevant because the firm has zero taxable profits in either case. When the profit rate is equal to economic depreciation (5\% in this example) the optimal strategy is to take only as much depreciation such that the net income reaches zero. In this case, 


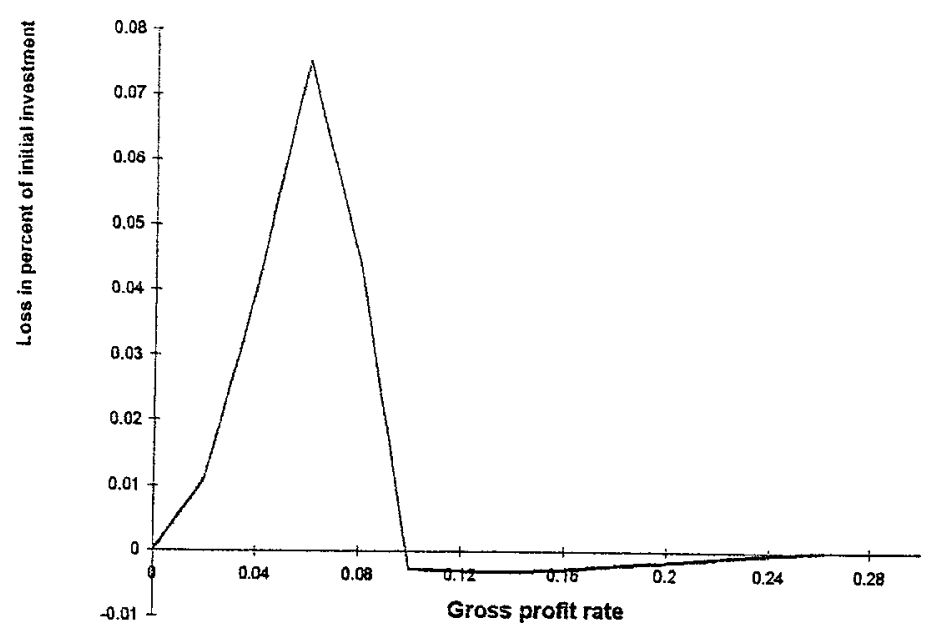

Figure 1. Present value of excess taxes when a firm always takes full tax depreciation compared to a case where maximal depreciation is constrained to net profits.

the firm can underutilize by setting the tax depreciation rate to the profit rate and achieve zero taxable profits in each period, until the asset is written off. This means that it will earn the net profits as early as possible without forgoing any principle repayment on zero interest loans (tax loss carryforwards) to the government. If it instead chooses to take full tax depreciation each year, some of the TLCF will expire before it can use them, and the firm will after 10 years start to lose TLCF and thereby experience higher taxes. In this particular example the loss reaches almost $8 \%$ of the value of the initial investment.

When the profit rate is higher than economic depreciation, the loss from taking full depreciation falls because the firm can utilize an increasing fraction of its loss carryforwards. ${ }^{18}$ The profit rate at which the two strategies again have equivalent effects depends on the expiration limit on loss carryforwards. In our example this occurs at about $10 \%$. Thus, for profit rates above $10 \%$, the firm should claim maximal depreciation.

The advantage from claiming full depreciation (and experiencing maximal tax losses) at high profit rates is never large. For this example, it never exceeds 0.4 percent of the initial investment. Since the profit stream from an investment is in fact stochastic, the optimal strategy for firms with TLCFs (ignoring other factors) is likely to include at least some underutilization of tax depreciation.

\subsection{Windowdressing}

Many research projects have found that firms manipulate their accounting numbers in order to report higher book income. ${ }^{19}$ These scholars suggest that reported book income is negatively correlated with the cost of new capital. The argument is based on asymmetric information between firms and capital providers, such as in the Myers and Majluf (1984) model of equity issuance, and the Stiglitz and Weiss (1981) model of credit rationing. 
These models predict that at least some firms will incur costs (such as underutilization) in order to obtain greater access to capital. Therefore, we hypothesize that firms in our sample might underutilize tax depreciation in order to "windowdress" their books. ${ }^{20}$

Norwegian accounting rules provide at least some firms with another incentive to windowdress, without any information asymmetry. When a corporation has lost two-thirds of its book equity, some costly and restrictive actions must be taken. A firm might underutilize depreciation deductions to reduce the probability of entering this formal state of financial distress.

As we have shown in Section 2, claimed tax depreciation in principle has no effect on book net income after the tax reform. ${ }^{21}$ Therefore, in our empirical analysis we will look not just for a relationship between book income and underutilization, but also for a lessening of that effect after the tax reform. In addition, to the extent that windowdressing arises from information asymmetries, we might expect that creditors will invest more in uncovering hidden information when providing larger amounts of financing. We look for evidence that windowdressing is more prevalent among smaller firms.

\subsection{Tax Administration Costs}

Aarbu (1994) found that in Norway a greater fraction of small corporations underutilize than large, but Kanniainen and Södersten (1994) found the opposite in Sweden and Finland. Both studies used approximately equivalent definitions of "small." Based on discussions with professional tax advisors in Norway, we hypothesize that an explanation may be found in tax system administrative costs. Norwegian tax law requires corporations to show the difference between tax valuation and book valuation for all assets. The most important source of such differences is the use of different tax and book depreciation. ${ }^{22}$ If there is a valuation difference, the corporation must fill in additional forms. Thus, reporting a difference between tax and book depreciation carries an administrative cost. ${ }^{23}$ If the tax saving from accelerated depreciation is small relative to the extra administrative cost then the corporation might underutilize accelerated tax depreciation in order to equalize it to book depreciation. ${ }^{24}$

\section{Econometric Specification and Method}

\subsection{The Dependent Variable}

The theory suggests that in general there will exist an internal solution to the optimal choice of tax depreciation. To make it easier to interpret the coefficients, we specify the dependent variable for the analysis as underutilization, equal to maximum utilization minus actual utilization. We can do this without loss of generality because the maximal allowable depreciation is exogenous. Since reported tax depreciation is constrained above by the maximum allowed and below by zero, we have a limited dependent variable that is doubly censored for every corporation. See the appendix for details on the construction of the dependent variable. 


\subsection{The Explanatory Variables}

4.2.1. The Dividend Constraint Because the dividend constraint is specified as an inequality in terms of observables, we can determine whether or not the firm is constrained at the margin. Equation (1) shows the identity between sources and uses of funds before the tax reform. We calculate dividends plus required allocations to the reserve fund. If these are equal to the sources (left-hand) side of (1), we conclude the firm is constrained: it must report lower depreciation to pay an additional dollar of dividends. Therefore, for the observations before the tax reform we construct a variable DIVC that is equal to one when this constraint is binding, and zero otherwise. ${ }^{25}$

The dividend constraint after the tax reform is based on book, not tax depreciation (see equation (3)). Therefore, after the tax reform we again define DIVC to be one if the constraint is binding, but now the constraint is stated in terms of book depreciation.

4.2.2. Competition Between Loss Carryforwards and Tax Depreciation In Section 3.3 we described the competition between depreciation deductions and tax loss carryforwards (TLCFs). If TLCFs did not expire, firms should always claim full depreciation ceteris paribus, even if it means delaying the recovery of TLCFs. However, most countries limit the number of years losses can be carried forward for deduction against future earnings, so deferred TLCFs may expire. ${ }^{26}$ Therefore, a firm might choose to underutilize depreciation deductions - thereby increasing current taxable income-in order to recover some of its loss carryforwards sooner.

The risk that tax loss deductions will expire unused depends on the likelihood that the firm will not have sufficient taxable income for the next several years. Altshuler and Auerbach (1990) showed that for US data a low-dimensional Markov model strongly predicted future tax-paying status. Therefore, to capture the effect of current and expected future tax exhaustion on the firm's incentive to underutilize depreciation allowances, we calculate a dummy variable, TAXP, equal to 1 when the firm is currently in a tax-paying status. ${ }^{27}$

The higher are loss carryforwards, the more that will be lost if they expire unused, and thus the more incentive there is to underutilize depreciation allowances. We therefore also include accumulated loss carryforwards, denoted TLCF, as a explanatory variable. ${ }^{28}$ Further, the substitution effect should be greater when loss carryforwards are close to expiration. ${ }^{29}$ We therefore include a variable, called OLDTLCF, which is loss carry forwards that expire within two years. ${ }^{30}$

4.2.3. Windowdressing Corporations with poor results may be inclined to windowdress their after-tax net income by underutilizing tax depreciation, as explained above. We construct two indicators for the economic condition of a corporation. First, we define a variable DIVP that is profit after tax given full utilization, calculated as the left-hand side of equation (1). ${ }^{31}$ A corporation that has negative income after tax with maximal utilization of depreciation may reduce the absolute value of its negative report by reducing depreciation, which raises its tax cost in the long but not the short run.

Another predictor that is often used to measure economic health is Altman's (1968) ZPROB, a discriminant function predictor of bankruptcies. Altman correctly classified 
94 percent of the corporations that went bankrupt the following year and 97 percent of those that did not. The measure is a weighted average of the following financial indicators: sales, operating result, working capital, retained earnings and market equity to book debt. ${ }^{32}$ A high ZPROB generally indicates less financial distress. ZPROB is scaled using total assets as denominator, so it can therefore take very large positive or negative values if total assets are small. We control for this by constraining ZPROB to a maximum absolute value of $50 .{ }^{33}$

4.2.4. Accounting Costs We suggested that accounting costs may induce some firms to equalize their reported tax and book depreciation. Discretion in the accounting rules makes it possible for firms to equalize by underutilizing tax depreciation, or, at least for many firms, by overreporting book depreciation. Reporting different depreciation amounts has administration costs; underutilizing tax depreciation raises tax payments; overreporting book depreciation presumably has adverse consequences for business planning and access to financial capital.

To test for the relationship between underutilization and depreciation equalization we construct a dummy variable (EQUALIZE) that is one if the accumulated tax debt in the start of the year is zero. Corporations that have accumulated tax debt equal to zero have always equalized tax values and book values. ${ }^{34}$ If in the current year corporations equalize depreciation by fully utilizing tax depreciation while overreporting book depreciation, then the coefficient will be negative. If corporations use book depreciation rates for tax depreciation (and thus underutilize), the coefficient on EQUALIZE will be positive. Of course, this explanation concerns administrative costs only if past equalization (EQUALIZE) is a good predictor of current accounting practice. We use this predictor to avoid endogeneity problems.

4.2.5. The Mix of Assets We also include a variable that is defined as the fraction of assets that are long-lived. We include this to control for the possibility that underutilization might be correlated with the asset mix. The cost of underutilization, as we have shown above, is the foregone interest on the tax savings, which must be deferred until the end of the depreciable life of the asset. Therefore, the cost of underutilization is lower when assets depreciate faster. ${ }^{35}$

4.2.6. Other Specification Issues We use lagged variables from the balance sheet to reduce the possibility of simultaneity bias. ${ }^{36}$ We also scale all variables in the regression equation with total sales, except ZPROB and TDEBT which are defined as fractions in the first place. ${ }^{37}$ However, after this normalization, we still observe substantial variation between corporations of different sizes. For that reason we divided the sample into four groups each year, according to the magnitude of financial income (SIZE) ${ }^{38}$ Group 1 consists of corporations that have less sales than 3 million NOK. Group 2 is from 3 million NOK to 20 million, group 3 ranges from 20 million to 100 million and group 4 contains corporations with sales higher than 100 million NOK. We are interested in the behavior of firms of all sizes, but we note that the group with the largest firms represents a dispro- 
Table 2. The expected correlation between underutilization and the regressors. $(\mathrm{A}(+)$ indicates that the corresponding hypothesis predicts a positive correlation between the explanatory variable and the dependent variable; a (-) indicates an expected negative correlation; and a blank indicates no prediction from the theory.)

\begin{tabular}{|c|c|c|c|c|c|c|}
\hline \multirow[b]{2}{*}{ Hypothesis } & \multicolumn{6}{|c|}{ Explanatory variables } \\
\hline & \multicolumn{3}{|c|}{ DIVC } & \multicolumn{2}{|l|}{ TDEBT } & DLDEBT \\
\hline Dividend constraint & \multicolumn{3}{|c|}{$\begin{array}{c}+ \text { (before tax reform) } \\
0 \text { (after tax reform) }\end{array}$} & & & \\
\hline \multirow[t]{2}{*}{ Monitoring costs } & & & & + & & + \\
\hline & DIVP & ZPROB & EQUALIZE & $\begin{array}{l}\text { LCARRY/ } \\
\text { LCARRY1 }\end{array}$ & TAXP & SDASSET \\
\hline Windowdressing & - & - & & & & \\
\hline Information costs/tax system costs & & & + & & & \\
\hline Competing deductions & & & & + & - & \\
\hline Asset mix & & & & & & $?$ \\
\hline
\end{tabular}

portionately large share of total Norwegian business assets. Generally speaking, the top 20 percent of firms own more than 80 percent of the total assets.

In Table 2 we summarize our hypotheses in terms of the explanatory variables, and indicate our predictions about the sign of the coefficients on these effects.

\subsection{Econometric Method}

Tax depreciation is censored by exogenous tax rules, which implies a particular structure for the stochastic component of our model. The maximum depreciation for corporation $j$ is $d^{\mathrm{max}}$, where we suppress the firm subscript $f$ for convenience (although it is important for the estimation that each firm has its own $d^{\max }$ ). Then,

$$
0 \leq d^{\mathrm{T}} \leq d^{\max }
$$

for all corporations. ${ }^{39} \mathrm{We}$ assume that the real unobserved (latent) variable $d^{*}$ has a normal distribution with mean $\mu$ and variance $\sigma^{2}$. Following Greene (1990) or Maddala (1983) we have the following specification for $d^{*}$ :

$$
\begin{aligned}
& d^{*}=\beta x+u, \\
& d^{\mathrm{T}}= \begin{cases}0 & \text { if } d^{*} \leq 0, \\
d^{*} & \text { if } 0<d^{*}<d^{\max }, \\
d^{\max } & \text { if } d^{*} \geq d^{\max },\end{cases}
\end{aligned}
$$

where $\beta$ is a vector of coefficients, $x$ is the vector of explanatory variables given above and $u$ is the disturbance vector. The probability of observing $d^{\mathrm{T}}=0$ is equal to

$$
P\left(d^{\mathrm{T}}=0\right)=P\left(d^{*} \leq 0\right)=P(-\beta x \geq u)=P\left(-\frac{\beta x}{\sigma} \geq \frac{u}{\sigma}\right)=F\left(\frac{\beta x}{\sigma}\right)=\Phi_{\mathrm{L} 1}
$$

where $F$ denotes the cumulative standard normal distribution. Similarly the probability for observing $d^{\mathrm{T}}=d^{\mathrm{max}}$ is equal to 


$$
\begin{aligned}
P\left(d^{\mathrm{T}}=d^{\max }\right) & =P\left(d^{*} \geq d^{\max }\right)=P\left(d^{\max }-\beta x \leq u\right) \\
& =P\left(\frac{d^{\max }-\beta x}{\sigma} \leq \frac{u}{\sigma}\right)=1-F\left(\frac{d^{\max }-\beta x}{\sigma}\right)=\Phi_{\mathrm{L} 2} .
\end{aligned}
$$

The probability for observing an uncensored observation is, with our notation, equal to $1-\Phi_{\mathrm{L} 2}-\Phi_{\mathrm{L} 1}$. Given these probabilities we can write our log likelihood function as

$$
\begin{aligned}
& L\left(\beta, \sigma^{2} \mid d^{\mathrm{T}}, x, d^{\max }\right) \\
& \quad=\sum_{i=0}^{N_{0}} \log \Phi_{\mathrm{L} 1}+\sum_{i=N_{0}+1}^{N_{\mathrm{A}}-1}\left(-\frac{1}{2} \log \left(2 \Pi \sigma^{2}\right)-\frac{1}{2 \sigma^{2}}\left(d^{\mathrm{T}}-\beta x\right)^{2}\right)+\sum_{i=N_{\max }}^{N} \log \Phi_{\mathrm{L} 2}
\end{aligned}
$$

where we have ordered the observations so that $N_{0}$ are the number of observations that are censored at zero, the last $N-N_{\max }$ are the number of observations that are censored at $d^{\max }$, and $N_{\max }-N_{0}$ are the number of uncensored observations. We maximize the likelihood function with respect to the unknown coefficient vector, $\beta$, and the unknown error variance, $\sigma^{2} .{ }^{40}$

\subsection{Data}

Data were provided by Statistics Norway's income and wealth surveys of Norwegian corporations. Statistics Norway is a government agency which extracts a stratified sample of about 6000 firms from the population of all firms that file tax returns. ${ }^{41}$ We provide a brief overview of the data; for a detailed description see Erstad (1990) and Nygaardsseter et al. (1995).

The agency collects the following tax forms:

- profit and loss,

- balance sheet with incoming and outgoing balance,

- income statement,

- tax depreciation statement for each asset group.

Almost every item on each form is coded, which creates an opportunity to study corporate behavior in detail. We use data for 1988, 1991, 1992 and 1993. Some corporations, like hydroelectric power plants, have different tax and depreciation rules, so we limit our sample to corporations in the industry groups for manufacturers, building and construction, merchandise, hotels and restaurants, transport and service business. We select only the corporations for which complete data are available for the variables we employ. We drop observations that have extreme losses compared to firm size. ${ }^{42}$ In addition we exclude firms that report sales less than $100,000 \mathrm{NOK}(\$ 11,000)$. After our selections we have a sample with approximately 1700 observations in 1988, 4400 in 1991 and 1992, and 2300 in 1993.

We provide summary statistics for the explanatory variables in Table 3. Refer to Table 1 for a summary of the dependent variable (underutilization). The mean value for each dummy variable is equal to the fraction of observations with a non-zero value. We can 
Table 3. Descriptive statistics. Explanatory variables. Mean and standard deviation (in parentheses).

\begin{tabular}{|c|c|c|c|c|c|c|c|c|}
\hline \multirow{2}{*}{$\frac{\text { Year }}{\text { Group }}$} & \multicolumn{4}{|c|}{1988} & \multicolumn{4}{|c|}{1991} \\
\hline & 1 & 2 & 3 & 4 & 1 & 2 & 3 & 4 \\
\hline DIVP & $\begin{array}{c}-0.096 \\
(0.544)\end{array}$ & $\begin{array}{c}0.017 \\
(0.160)\end{array}$ & $\begin{array}{c}0.014 \\
(0.062)\end{array}$ & $\begin{array}{c}0.009 \\
(0.030)\end{array}$ & $\begin{array}{r}-0.038 \\
(0.174)\end{array}$ & $\begin{array}{r}-0.000 \\
(0.097)\end{array}$ & $\begin{array}{c}0.007 \\
(0.081)\end{array}$ & $\begin{array}{c}0.012 \\
(0.079)\end{array}$ \\
\hline DIVC & $\begin{array}{c}0.085 \\
(0.279)\end{array}$ & $\begin{array}{c}0.068 \\
(0.253)\end{array}$ & $\begin{array}{c}0.051 \\
(0.220)\end{array}$ & $\begin{array}{c}0.042 \\
(0.202)\end{array}$ & $\begin{array}{c}0.134 \\
(0.341)\end{array}$ & $\begin{array}{c}0.079 \\
(0.270)\end{array}$ & $\begin{array}{c}0.025 \\
(0.157)\end{array}$ & $\begin{array}{c}0.012 \\
(0.110)\end{array}$ \\
\hline TDEBT & $\begin{array}{c}0.031 \\
(0.046)\end{array}$ & $\begin{array}{c}0.058 \\
(0.046)\end{array}$ & $\begin{array}{c}0.074 \\
(0.052)\end{array}$ & $\begin{array}{c}0.077 \\
(0.046)\end{array}$ & $\begin{array}{c}0.028 \\
(0.050)\end{array}$ & $\begin{array}{c}0.037 \\
(0.048)\end{array}$ & $\begin{array}{c}0.047 \\
(0.048)\end{array}$ & $\begin{array}{c}0.061 \\
(0.053)\end{array}$ \\
\hline DLDEBT & $\begin{array}{c}0.087 \\
(1.292)\end{array}$ & $\begin{array}{c}0.024 \\
(0.178)\end{array}$ & $\begin{array}{c}0.028 \\
(0.214)\end{array}$ & $\begin{array}{c}0.010 \\
(0.071)\end{array}$ & $\begin{array}{c}0.025 \\
(0.271)\end{array}$ & $\begin{array}{c}0.032 \\
(0.458)\end{array}$ & $\begin{array}{c}0.001 \\
(0.104)\end{array}$ & $\begin{array}{r}-0.000 \\
(0.092)\end{array}$ \\
\hline ZPROB & $\begin{array}{c}1.962 \\
(3.547)\end{array}$ & $\begin{array}{c}3.105 \\
(3.470)\end{array}$ & $\begin{array}{c}3.110 \\
(3.332)\end{array}$ & $\begin{array}{c}2.920 \\
(3.153)\end{array}$ & $\begin{array}{c}4.189 \\
(7.129)\end{array}$ & $\begin{array}{l}5.318 \\
(8.278)\end{array}$ & $\begin{array}{c}4.011 \\
(5.852)\end{array}$ & $\begin{array}{c}3.323 \\
(3.242)\end{array}$ \\
\hline EQUALIZE & $\begin{array}{c}0.425 \\
(0.495)\end{array}$ & $\begin{array}{c}0.125 \\
(0.331)\end{array}$ & $\begin{array}{c}0.037 \\
(0.189)\end{array}$ & $\begin{array}{c}0.015 \\
(0.122)\end{array}$ & $\begin{array}{c}0.462 \\
(0.498)\end{array}$ & $\begin{array}{c}0.264 \\
(0.441)\end{array}$ & $\begin{array}{c}0.137 \\
(0.344)\end{array}$ & $\begin{array}{c}0.080 \\
(0.272)\end{array}$ \\
\hline TLCF & $\begin{array}{c}0.047 \\
(0.116)\end{array}$ & $\begin{array}{c}0.006 \\
(0.036)\end{array}$ & $\begin{array}{c}0.003 \\
(0.052)\end{array}$ & $\begin{array}{c}0.001 \\
(0.009)\end{array}$ & $\begin{array}{c}0.085 \\
(0.175)\end{array}$ & $\begin{array}{c}0.047 \\
(0.124)\end{array}$ & $\begin{array}{c}0.034 \\
(0.096)\end{array}$ & $\begin{array}{c}0.021 \\
(0.074)\end{array}$ \\
\hline OLDTLCF & $\mathrm{Na}$ & $\mathrm{Na}$ & $\mathrm{Na}$ & $\mathrm{Na}$ & $\begin{array}{r}<0.001 \\
(0.006)\end{array}$ & $\begin{array}{r}<0.001 \\
(0.009)\end{array}$ & $\begin{array}{r}<0.001 \\
(0.003)\end{array}$ & $\begin{array}{r}<0.001 \\
(0.006)\end{array}$ \\
\hline TAXP & $\begin{array}{c}0.539 \\
(0.499)\end{array}$ & $\begin{array}{c}0.765 \\
(0.424)\end{array}$ & $\begin{array}{c}0.843 \\
(0.363)\end{array}$ & $\begin{array}{c}0.868 \\
(0.338)\end{array}$ & $\begin{array}{c}0.486 \\
(0.500)\end{array}$ & $\begin{array}{c}0.622 \\
(0.484)\end{array}$ & $\begin{array}{c}0.625 \\
(0.484)\end{array}$ & $\begin{array}{c}0.636 \\
(0.481)\end{array}$ \\
\hline SDASSET & $\begin{array}{c}0.095 \\
(0.270)\end{array}$ & $\begin{array}{c}0.134 \\
(0.277)\end{array}$ & $\begin{array}{c}0.184 \\
(0.290)\end{array}$ & $\begin{array}{c}0.236 \\
(0.276)\end{array}$ & $\begin{array}{c}0.068 \\
(0.228)\end{array}$ & $\begin{array}{c}0.106 \\
(0.257)\end{array}$ & $\begin{array}{c}0.152 \\
(0.271)\end{array}$ & $\begin{array}{c}0.216 \\
(0.271)\end{array}$ \\
\hline Year & \multicolumn{4}{|c|}{1992} & \multicolumn{4}{|c|}{1993} \\
\hline Group & 1 & 2 & 3 & 4 & 1 & 2 & 3 & 4 \\
\hline IVP & $\begin{array}{c}-0.012 \\
(0.181)\end{array}$ & $\begin{array}{c}0.002 \\
(0.165)\end{array}$ & $\begin{array}{c}0.009 \\
(0.104)\end{array}$ & $\begin{array}{c}0.018 \\
(0.080)\end{array}$ & $\begin{array}{c}0.016 \\
(0.199)\end{array}$ & $\begin{array}{c}0.019 \\
(0.088)\end{array}$ & $\begin{array}{c}0.019 \\
(0.078)\end{array}$ & $\begin{array}{c}0.029 \\
(0.080)\end{array}$ \\
\hline DIVC & $\begin{array}{c}0.060 \\
(0.238)\end{array}$ & $\begin{array}{c}0.025 \\
10.156)\end{array}$ & $\begin{array}{c}0.010 \\
(0.100)\end{array}$ & $\begin{array}{c}0.001 \\
(0.034)\end{array}$ & $\begin{array}{c}0.060 \\
(0.237)\end{array}$ & $\begin{array}{c}0.015 \\
(0.121)\end{array}$ & $\begin{array}{c}0.008 \\
(0.090)\end{array}$ & $\begin{array}{c}0.002 \\
(0.054)\end{array}$ \\
\hline TDEBT & $\begin{array}{c}0.006 \\
(0.018)\end{array}$ & $\begin{array}{c}0.009 \\
(0.018)\end{array}$ & $\begin{array}{c}0.018 \\
(0.129)\end{array}$ & $\begin{array}{c}0.023 \\
(0.027)\end{array}$ & $\begin{array}{c}0.005 \\
(0.015)\end{array}$ & $\begin{array}{c}0.008 \\
(0.020)\end{array}$ & $\begin{array}{c}0.012 \\
(0.021)\end{array}$ & $\begin{array}{c}0.018 \\
(0.026)\end{array}$ \\
\hline DLDEBT & $\begin{array}{c}0.010 \\
(0.248)\end{array}$ & $\begin{array}{c}0.005 \\
(0.201)\end{array}$ & $\begin{array}{c}-0.008 \\
(0.114)\end{array}$ & $\begin{array}{c}0.004 \\
(0.122)\end{array}$ & $\begin{array}{c}0.0033 \\
(0.494)\end{array}$ & $\begin{array}{c}-0.005 \\
(0.147)\end{array}$ & $\begin{array}{c}0.003 \\
(0.141)\end{array}$ & $\begin{array}{c}-0.002 \\
(0.075)\end{array}$ \\
\hline ZPROB & $\begin{array}{c}3.571 \\
(5.152)\end{array}$ & $\begin{array}{c}4.606 \\
(6.325)\end{array}$ & $\begin{array}{c}3.954 \\
(3.801)\end{array}$ & $\begin{array}{c}3.476 \\
(3.961)\end{array}$ & $\begin{array}{c}3.346 \\
(3.863)\end{array}$ & $\begin{array}{c}3.753 \\
(2.699)\end{array}$ & $\begin{array}{c}3.498 \\
(2.628)\end{array}$ & $\begin{array}{c}3.422 \\
(2.405)\end{array}$ \\
\hline EQUALIZE & $\begin{array}{c}0.715 \\
(0.451)\end{array}$ & $\begin{array}{c}0.539 \\
(0.498)\end{array}$ & $\begin{array}{c}0.399 \\
(0.490)\end{array}$ & $\begin{array}{c}0.284 \\
(0.451)\end{array}$ & $\begin{array}{c}0.690 \\
(0.463)\end{array}$ & $\begin{array}{c}0.592 \\
(0.491)\end{array}$ & $\begin{array}{c}0.452 \\
(0.497)\end{array}$ & $\begin{array}{c}0.359 \\
(0.480)\end{array}$ \\
\hline TLCF & $\begin{array}{c}0.099 \\
(0.184)\end{array}$ & $\begin{array}{c}0.046 \\
(0.115)\end{array}$ & $\begin{array}{c}0.035 \\
(0.095)\end{array}$ & $\begin{array}{c}0.029 \\
(0.091)\end{array}$ & $\begin{array}{c}0.093 \\
(0.187)\end{array}$ & $\begin{array}{c}0.052 \\
(0.125)\end{array}$ & $\begin{array}{c}0.040 \\
(0.114)\end{array}$ & $\begin{array}{c}0.029 \\
(0.092)\end{array}$ \\
\hline OLDTLCF & $\begin{array}{c}0.001 \\
(0.013)\end{array}$ & $\begin{array}{r}<0.001 \\
(0.002)\end{array}$ & $\begin{array}{r}<0.001 \\
(0.001)\end{array}$ & $\begin{array}{c}0.001 \\
(0.015)\end{array}$ & $\begin{array}{r}<0.001 \\
(0.003)\end{array}$ & $\begin{array}{c}0.001 \\
(0.011)\end{array}$ & $\begin{array}{r}<0.001 \\
(0.003)\end{array}$ & $\begin{array}{c}0.001 \\
(0.013)\end{array}$ \\
\hline TAXP & $\begin{array}{c}0.593 \\
(0.491)\end{array}$ & $\begin{array}{c}0.704 \\
(0.456)\end{array}$ & $\begin{array}{c}0.764 \\
(0.424)\end{array}$ & $\begin{array}{c}0.753 \\
(0.431)\end{array}$ & $\begin{array}{c}0.653 \\
(0.476)\end{array}$ & $\begin{array}{c}0.746 \\
(0.435)\end{array}$ & $\begin{array}{c}0.781 \\
(0.413)\end{array}$ & $\begin{array}{c}0.798 \\
(0.401)\end{array}$ \\
\hline SDASSET & $\begin{array}{c}0.105 \\
(0.276)\end{array}$ & $\begin{array}{c}0.159 \\
(0.320)\end{array}$ & $\begin{array}{c}0.198 \\
(0.429)\end{array}$ & $\begin{array}{c}0.273 \\
(0.303)\end{array}$ & $\begin{array}{c}0.105 \\
(0.273)\end{array}$ & $\begin{array}{c}0.194 \\
(0.341)\end{array}$ & $\begin{array}{c}0.222 \\
(0.566)\end{array}$ & $\begin{array}{c}0.255 \\
(0.310)\end{array}$ \\
\hline
\end{tabular}

Notes: (a) < means less than. (b) Around 50 percent of the firms in the smallest size groups report loss carry forwards. This fraction declines with size to about 35 percent for the largest size group. 
observe some interesting facts related to our hypotheses. For example, the dividend constraint may induce firms to underutilize depreciation. However, in all size groups and in every year a much smaller percentage of firms are constrained than are underutilizing. Of course, we may find that for those firms the constraint is a significant explanation for underutilization. We also see declining use of tax and book account equalization with a larger firm size, consistent with our prior belief about relatively higher tax administration costs among small firms.

\section{Statistical Results}

We present our regression results in Table 4. We divide firms into groups according to total income (SIZE), with Group 1 the smallest firms and Group 4 the largest. We then estimate separate regressions for each group, for each year. The dependent variable is the amount of underutilization. The $p$-values are given in parentheses, denoting the probability of observing the estimated value if the null hypothesis (of a zero coefficient) is true.

Table 4. Regression results. Dependent variable: underutilization.

\begin{tabular}{|c|c|c|c|c|c|c|c|c|}
\hline \multirow{2}{*}{$\frac{\text { Year }}{\text { Group }}$} & \multicolumn{4}{|c|}{1988} & \multicolumn{4}{|c|}{1991} \\
\hline & 1 & 2 & 3 & 4 & 1 & 2 & 3 & 4 \\
\hline Intercept & $\begin{array}{r}-0.0594 \\
(0.0022)\end{array}$ & $\begin{array}{r}-0.0056 \\
(0.1278)\end{array}$ & $\begin{array}{r}-0.0038 \\
(0.5623)\end{array}$ & $\begin{array}{c}0.0015 \\
(0.6986)\end{array}$ & $\begin{array}{r}-0.0266 \\
(0.0009)\end{array}$ & $\begin{array}{r}-0.0137 \\
(0.0001)\end{array}$ & $\begin{array}{r}-0.0087 \\
(0.0001)\end{array}$ & $\begin{array}{r}-0.0178 \\
\quad(0.0001)\end{array}$ \\
\hline DIVP & $\begin{array}{r}-0.0666 \\
(0.0001)\end{array}$ & $\begin{array}{r}-0.0089 \\
(0.2809)\end{array}$ & $\begin{array}{c}-0.2014 \\
(0.0001)\end{array}$ & $\begin{array}{r}-0.3210 \\
(0.0001)\end{array}$ & $\begin{array}{r}-0.1085 \\
(0.0001)\end{array}$ & $\begin{array}{r}-0.1136 \\
(0.0001)\end{array}$ & $\begin{array}{c}-0.1641 \\
(0.0001)\end{array}$ & $\begin{array}{r}-0.3015 \\
(0.0001)\end{array}$ \\
\hline DIVC & $\begin{array}{c}0.0085 \\
(0.7599)\end{array}$ & $\begin{array}{c}0.0119 \\
(0.0229)\end{array}$ & $\begin{array}{r}-0.0076 \\
(0.4940)\end{array}$ & $\begin{array}{c}0.0020 \\
(0.7111)\end{array}$ & $\begin{array}{c}0.0274 \\
(0.0054)\end{array}$ & $\begin{array}{c}0.0021 \\
(0.6864)\end{array}$ & $\begin{array}{c}0.0025 \\
(0.7161)\end{array}$ & $\begin{array}{r}-0.0083 \\
(0.6191)\end{array}$ \\
\hline TDEBT & $\begin{array}{c}0.0376 \\
(0.8741)\end{array}$ & $\begin{array}{c}0.1042 \\
(0.0023)\end{array}$ & $\begin{array}{c}0.0541 \\
(0.2244)\end{array}$ & $\begin{array}{c}0.0508 \\
(0.0520)\end{array}$ & $\begin{array}{r}-0.1804 \\
(0.0349)\end{array}$ & $\begin{array}{c}0.0296 \\
(0.3910)\end{array}$ & $\begin{array}{c}0.0357 \\
(0.1975)\end{array}$ & $\begin{array}{r}0.0926 \\
(0.0114)\end{array}$ \\
\hline DLDEBT & $\begin{array}{c}0.0051 \\
(0.3386)\end{array}$ & $\begin{array}{c}0.0083 \\
(0.2466)\end{array}$ & $\begin{array}{c}0.0327 \\
(0.0003)\end{array}$ & $\begin{array}{c}0.0008 \\
(0.9550)\end{array}$ & $\begin{array}{c}0.0243 \\
(0.0403)\end{array}$ & $\begin{array}{c}0.0096 \\
(0.0002)\end{array}$ & $\begin{array}{r}-0.0115 \\
(0.2349)\end{array}$ & $\begin{array}{r}0.0579 \\
(0.0038)\end{array}$ \\
\hline ZPROB & $\begin{array}{c}0.0013 \\
(0.5013)\end{array}$ & $\begin{array}{r}-0.0002 \\
(0.4716)\end{array}$ & $\begin{array}{r}-0.0003 \\
(0.6230)\end{array}$ & $\begin{array}{r}-0.0008 \\
(0.2611)\end{array}$ & $\begin{array}{r}-0.0003 \\
(0.5239)\end{array}$ & $\begin{array}{r}-0.0002 \\
(0.1821)\end{array}$ & $\begin{array}{c}-0.0001 \\
(0.5520)\end{array}$ & $\begin{array}{r}-0.0009 \\
\quad(0.1670)\end{array}$ \\
\hline EQUALIZE & $\begin{array}{c}0.0574 \\
(0.0051)\end{array}$ & $\begin{array}{c}0.0207 \\
(0.0001)\end{array}$ & $\begin{array}{c}0.0086 \\
(0.4807)\end{array}$ & $\begin{array}{c}0.0514 \\
(0.0001)\end{array}$ & $\begin{array}{c}0.0194 \\
(0.0165)\end{array}$ & $\begin{array}{c}0.0181 \\
(0.0001)\end{array}$ & $\begin{array}{c}0.0074 \\
(0.0311)\end{array}$ & $\begin{array}{c}0.0012 \\
(0.0644)\end{array}$ \\
\hline TLCF & $\begin{array}{c}0.0176 \\
(0.7925)\end{array}$ & $\begin{array}{r}-0.0003 \\
(0.9912)\end{array}$ & $\begin{array}{r}-0.0758 \\
(0.7899)\end{array}$ & $\begin{array}{c}0.3190 \\
(0.0001)\end{array}$ & $\begin{array}{c}0.0444 \\
(0.0177)\end{array}$ & $\begin{array}{c}0.0238 \\
(0.0344)\end{array}$ & $\begin{array}{c}0.0326 \\
(0.0070)\end{array}$ & $\begin{array}{r}0.0375 \\
\quad(0.1069)\end{array}$ \\
\hline OLDTLCF & $\mathrm{Na}$ & $\mathrm{Na}$ & $\mathrm{Na}$ & $\mathrm{Na}$ & $\begin{array}{c}0.3510 \\
(0.4071)\end{array}$ & $\begin{array}{c}0.4603 \\
(0.0170)\end{array}$ & $\begin{array}{r}-0.2317 \\
(0.4788)\end{array}$ & $\begin{array}{r}0.6840 \\
(0.0099)\end{array}$ \\
\hline TAXP & $\begin{array}{r}-0.0620 \\
(0.0005)\end{array}$ & $\begin{array}{r}-0.0275 \\
(0.0001)\end{array}$ & $\begin{array}{r}-0.0265 \\
(0.0001)\end{array}$ & $\begin{array}{r}-0.0137 \\
(0.0003)\end{array}$ & $\begin{array}{r}-0.0550 \\
(0.0001)\end{array}$ & $\begin{array}{r}-0.0215 \\
(0.0001)\end{array}$ & $\begin{array}{r}-0.0168 \\
(0.0001)\end{array}$ & $\begin{array}{r}-0.0095 \\
\quad(0.0139)\end{array}$ \\
\hline SDASSET & $\begin{array}{c}0.0365 \\
(0.1920)\end{array}$ & $\begin{array}{c}0.0033 \\
(0.5084)\end{array}$ & $\begin{array}{c}0.0060 \\
(0.4477)\end{array}$ & $\begin{array}{c}0.0050 \\
(0.2619)\end{array}$ & $\begin{array}{c}0.0145 \\
(0.3122)\end{array}$ & $\begin{array}{c}0.0086 \\
(0.1093)\end{array}$ & $\begin{array}{c}0.0111 \\
(0.0050)\end{array}$ & $\begin{array}{r}0.0220 \\
(0.0005)\end{array}$ \\
\hline Log Likelihood & 0.70 & 273.72 & 155.57 & 206.17 & 94.84 & 477.49 & 644.50 & 356.72 \\
\hline Standard error of the estimate & 0.109 & 0.026 & 0.037 & 0.016 & 0.334 & 0.050 & 0.036 & 0.046 \\
\hline Fraction non-censored (\%) & 36.60 & 32.20 & 33.60 & 34.30 & 38.90 & 38.10 & 39.30 & 39.90 \\
\hline Fraction full utilization (\%) & 61.80 & 66.90 & 66.00 & 63.90 & 58.00 & 59.80 & 58.80 & 57.30 \\
\hline
\end{tabular}


Table 4. (Continued.)

\begin{tabular}{|c|c|c|c|c|c|c|c|c|}
\hline \multirow{2}{*}{$\frac{\text { Year }}{\text { Group }}$} & \multicolumn{4}{|c|}{1992} & \multicolumn{4}{|c|}{1993} \\
\hline & 1 & 2 & 3 & 4 & 1 & 2 & 3 & 4 \\
\hline Intercept & $\begin{array}{r}-0.0590 \\
(0.0001)\end{array}$ & $\begin{array}{r}-0.0266 \\
(0.0001)\end{array}$ & $\begin{array}{r}-0.0122 \\
(0.0001)\end{array}$ & $\begin{array}{c}-0.0146 \\
(0.0001)\end{array}$ & $\begin{array}{c}-0.0590 \\
(0.0001)\end{array}$ & $\begin{array}{r}-0.0112 \\
(0.0066)\end{array}$ & $\begin{array}{r}-0.0163 \\
(0.0002)\end{array}$ & $\begin{array}{r}-0.0223 \\
(0.0001)\end{array}$ \\
\hline DIVP & $\begin{array}{r}-0.0532 \\
(0.0004)\end{array}$ & $\begin{array}{c}0.0096 \\
(0.3814)\end{array}$ & $\begin{array}{c}0.0096 \\
(0.3468)\end{array}$ & $\begin{array}{r}-0.0303 \\
(0.0290)\end{array}$ & $\begin{array}{r}-0.0266 \\
(0.1636)\end{array}$ & $\begin{array}{c}0.0023 \\
(0.8802)\end{array}$ & $\begin{array}{r}-0.0065 \\
(0.7587)\end{array}$ & $\begin{array}{r}-0.0061 \\
(0.7027)\end{array}$ \\
\hline DIVC & $\begin{array}{c}0.0265 \\
(0.0141)\end{array}$ & $\begin{array}{c}0.0115 \\
(0.2287)\end{array}$ & $\begin{array}{c}0.0076 \\
(0.3436)\end{array}$ & $\begin{array}{r}-0.0561 \\
(0.9047)\end{array}$ & $\begin{array}{c}0.0091 \\
(0.5973)\end{array}$ & $\begin{array}{r}-0.0953 \\
(0.9996)\end{array}$ & $\begin{array}{r}-0.0026 \\
(0.8813)\end{array}$ & $\begin{array}{r}-0.0542 \\
(0.8792)\end{array}$ \\
\hline TDEBT & $\begin{array}{c}0.0302 \\
(0.8750)\end{array}$ & $\begin{array}{c}0.1361 \\
(0.1560)\end{array}$ & $\begin{array}{r}-0.0222 \\
(0.6316)\end{array}$ & $\begin{array}{c}0.0260 \\
(0.5439)\end{array}$ & $\begin{array}{c}0.2512 \\
(0.4722)\end{array}$ & $\begin{array}{r}-0.0350 \\
(0.6536)\end{array}$ & $\begin{array}{c}0.0158 \\
(0.8359)\end{array}$ & $\begin{array}{r}0.0767 \\
(0.2327)\end{array}$ \\
\hline DLDEBT & $\begin{array}{c}0.0327 \\
(0.0004)\end{array}$ & $\begin{array}{c}0.0129 \\
(0.0321)\end{array}$ & $\begin{array}{c}0.0017 \\
(0.8153)\end{array}$ & $\begin{array}{c}0.0124 \\
(0.0631)\end{array}$ & $\begin{array}{r}-0.0065 \\
(0.4661)\end{array}$ & $\begin{array}{c}-0.0112 \\
(0.1827)\end{array}$ & $\begin{array}{c}0.0073 \\
(0.4590)\end{array}$ & $\begin{array}{r}0.0110 \\
(0.4889)\end{array}$ \\
\hline ZPROB & $\begin{array}{r}-0.0008 \\
(0.1828)\end{array}$ & $\begin{array}{c}-0.0001 \\
(0.6278)\end{array}$ & $\begin{array}{c}-0.0002 \\
(0.3005)\end{array}$ & $\begin{array}{r}-0.0002 \\
(0.4056)\end{array}$ & $\begin{array}{c}0.0003 \\
(0.6155)\end{array}$ & $\begin{array}{r}-0.0008 \\
(0.1258)\end{array}$ & $\begin{array}{r}-0.0006 \\
(0.2949)\end{array}$ & $\begin{array}{r}-0.0010 \\
(0.1867)\end{array}$ \\
\hline EQUALIZE & $\begin{array}{c}0.0205 \\
(0.0123)\end{array}$ & $\begin{array}{c}0.0064 \\
(0.0937)\end{array}$ & $\begin{array}{c}0.0018 \\
(0.4098)\end{array}$ & $\begin{array}{c}0.0027 \\
(0.3257)\end{array}$ & $\begin{array}{c}0.0266 \\
(0.0334)\end{array}$ & $\begin{array}{c}0.0027 \\
(0.3899)\end{array}$ & $\begin{array}{c}0.0018 \\
(0.6138)\end{array}$ & $\begin{array}{r}0.0089 \\
(0.0172)\end{array}$ \\
\hline TLCF & $\begin{array}{r}-0.0098 \\
(0.5121)\end{array}$ & $\begin{array}{c}0.0530 \\
(0.0001)\end{array}$ & $\begin{array}{c}0.0186 \\
(0.0475)\end{array}$ & $\begin{array}{c}0.0030 \\
(0.7840)\end{array}$ & $\begin{array}{c}0.0419 \\
(0.0145)\end{array}$ & $\begin{array}{c}0.0156 \\
(0.1248)\end{array}$ & $\begin{array}{r}-0.0186 \\
(0.2208)\end{array}$ & $\begin{array}{r}0.0340 \\
(0.0147)\end{array}$ \\
\hline OLDTLCF & $\begin{array}{c}0.1056 \\
(0.5266)\end{array}$ & $\begin{array}{c}0.6196 \\
(0.2383)\end{array}$ & $\begin{array}{c}0.1143 \\
(0.8345)\end{array}$ & $\begin{array}{c}0.0163 \\
(0.7941)\end{array}$ & $\begin{array}{r}-1.7380 \\
(0.9124)\end{array}$ & $\begin{array}{c}0.0405 \\
(0.6157)\end{array}$ & $\begin{array}{r}-0.0607 \\
(0.9302)\end{array}$ & $\begin{array}{r}0.0532 \\
(0.5560)\end{array}$ \\
\hline TAXP & $\begin{array}{r}-0.0269 \\
(0.0001)\end{array}$ & $\begin{array}{c}-0.0225 \\
(0.0001)\end{array}$ & $\begin{array}{c}-0.0121 \\
(0.0001)\end{array}$ & $\begin{array}{r}-0.0088 \\
(0.0003)\end{array}$ & $\begin{array}{r}-0.0217 \\
(0.0110)\end{array}$ & $\begin{array}{r}-0.0101 \\
(0.0007)\end{array}$ & $\begin{array}{r}-0.0193 \\
(0.0001)\end{array}$ & $\begin{array}{r}-0.0118 \\
(0.0007)\end{array}$ \\
\hline SDASSET & $\begin{array}{c}0.0136 \\
(0.1540)\end{array}$ & $\begin{array}{c}0.0127 \\
(0.0061)\end{array}$ & $\begin{array}{c}0.0046 \\
(0.0844)\end{array}$ & $\begin{array}{c}0.0069 \\
(0.0498)\end{array}$ & $\begin{array}{c}0.0151 \\
(0.2484)\end{array}$ & $\begin{array}{c}0.0037 \\
(0.3109)\end{array}$ & $\begin{array}{c}0.0031 \\
(0.1515)\end{array}$ & $\begin{array}{r}0.0132 \\
(0.0073)\end{array}$ \\
\hline Log Likelihood & 31.39 & 216.44 & 404.05 & 274.13 & 16.6781 & 109.77 & 126.18 & 139.59 \\
\hline Standard error of the estimate & 0.061 & 0.037 & 0.024 & 0.022 & 0.047 & 0.018 & 0.030 & 0.026 \\
\hline Fraction non-censored (\%) & 20.20 & 23.30 & 25.00 & 24.40 & 15.67 & 18.24 & 17.70 & 19.88 \\
\hline Fraction full utilization (\%) & 79.80 & 76.70 & 75.00 & 75.60 & 84.33 & 81.76 & 82.30 & 80.12 \\
\hline
\end{tabular}

\subsection{The Dividend Constraint Hypothesis}

We predicted that before the tax reform a binding constraint on dividends (indicated by DIVC $=1$ ) would induce depreciation underutilization, to loosen the constraint. This would be indicated by a positive coefficient.

We do not find strong support for the dividend constraint hypothesis. Six out of eight of the pre-reform coefficients are positive, but only two of these are statistically significant at a 5\% level. (Four out of eight coefficients are positive post-reform, when we expected no effect, but only one of these is significant at the 5\% level.) One reason for this negative result may be that a very low fraction of firms are dividend constrained (see Table 3). Norwegian firms generally pay a low fraction of their income as dividends (most of the income is retained). ${ }^{43}$ Only about $5 \%$ of the firms in our sample were constrained in the pre-reform years. Thus, we simply may not have enough observations for reliable estimation of this effect. Another possible explanation for the lack of an observed prereform effect is that 1991 was the end of a recession period that started in 1989 and the market had low expectations regarding profits and dividends. When expectations are low, it is less likely that firms will face an effective dividend constraint. 


\subsection{Competition Between Tax Losses and Tax Depreciation}

If tax losses could be carried forward forever, firms should utilize all depreciation deductions immediately, independent of the firm's tax loss position, because losses can be recovered sooner than postponed depreciation deductions. However, since tax losses do expire, a firm at risk of losing its loss carryforwards should underutilize some amount of depreciation in order to recover more of the tax loss.

All of the coefficients on the tax-paying dummy (TAXP) have the predicted positive sign, and all are very precise. Indeed, nearly all are significant at better than the $1 \%$ level. This is by far the strongest and most robust result we have obtained: When firms are earning tax losses they underutilize tax depreciation.

We tested the tax loss effect further by including the level of the firm's loss carryforwards, and the level of its carryforwards that were within two years of expiration. The results are mixed and overall neither confirm nor reject the main effect. The evidence is slightly more supportive for near-expiration carryforwards, as we expected. The problem may be that the level of carryforwards may not be sufficiently correlated with the likelihood that carryforwards will expire unused, given that the currently tax-paying dummy variable is already in the model.

\subsection{The Windowdressing Hypothesis}

If a firm is windowdressing, we expect it to report higher income when its results are poor by claiming lower depreciation deductions. Thus, we expect negative coefficients on our measures of profitability (DIVP) and financial health (ZPROB).

We see three important results in Table 4. First, the windowdressing hypothesis is strongly confirmed in the period before the tax reform (1988 and 1991). Second, windowdressing is less important after the tax reform, especially for medium and large corporations. We expected this result, due to the change from uniform to separate reporting: it is now possible to claim full tax deductions while separately dressing the financial books. Third, for small corporations we find that windowdressing is important both before and after the tax reform. This confirms our belief that reporting conventions matter less for small firms, because they tend to equalize tax and book depreciation in any case to reduce administrative costs. Thus, the incentive for windowdressing persists even after the change in accounting rules.

We estimate that small firms on average lower their tax depreciation by $0.01-0.14$ NOK when their book result is lowered by 1 NOK. ${ }^{44}$ The effect is much stronger in 1991 than in 1988, perhaps due to macroeconomic conditions. Our estimate of the marginal effect for the 1988 economic boom was 0.03 . Our estimate was 0.14 for the 1991 recession year. In a recession, average profits are low or negative, and borrowing is more likely constrained. Both effects suggest more windowdressing. The marginal effect is roughly the same over this period for larger firms, perhaps because the sources of financial capital for large firms are not as sensitive to cyclical fluctuations.

We expect a negative coefficient estimate on ZPROB, our measure of financial health. We consistently find this result among all but the smallest firms, although not many of the 
estimates are statistically significant. The results for smaller (Group 1) firms are mixed and insignificant. Since a low ZPROB ratio for a small firm generally indicates a low level of cash reserves, we suspect the demand for cash (from lower current taxes) may outweigh the desire to "dress up," holding profitability constant. Recall, the profit indicator of windowdressing (DIVP) was strong for small firms.

\subsection{Accounting System Costs}

We predicted that some firms might underutilize tax depreciation in order to equalize their tax and book accounts, and thus avoid various costs of maintaining two sets of books. EQUALIZE is a dummy variable that is one for firms that have zero accumulated tax debt, and thus have been equalizing tax and book depreciation in prior years. EQUALIZE is equal to 1 for $40-70 \%$ of Group 1 firms over the sample, but fewer as firm size increases. Firms incur financial or informational costs when they equalize depreciation, which they can do by underutilizing tax depreciation or overreporting book depreciation. From the many firms incurring these costs we infer that the tax administration costs of maintaining separate books are significant. Further, if the coefficient on EQUALIZE is positive, then firms that equalize tax and book depreciation tend to do so by underutilizing tax depreciation, presumably because they find that less costly than overreporting book depreciation. If firms are instead equalizing depreciation by overreporting depreciation on the financial accounts, then the coefficient on EQUALIZE should be zero or negative.

The results in Table 4 confirm the hypothesis that accounting administration costs induce underutilization of tax depreciation. All of the estimated coefficients have the predicted positive sign; somewhat more than half of the estimated coefficients are statistically significant at the 5\% level. Firms that equalize tax and book depreciation have higher underutilization than firms that do not equalize. The effect is stronger for small firms, which we expected because the approximately fixed accounting cost of differential depreciation reporting is less important for larger firms.

\subsection{Other Results}

We include two variables in our regressions to test the monitoring hypothesis of Kanniainen and Södersten (1994). These authors predicted that firms would forego some accelerated depreciation deductions when agency costs were significant. As suggested by Jensen and Meckling (1976) and Jensen (1986) agency problems can be ameliorated by private debt holders through monitoring, and by shareholders by increasing the interest-bearing debt load of the firm (thus pre-committing payments out of free cash flows). Accelerated depreciation deductions are interest-free, unmonitored (government owned) debt, and thus do not provide the same agency benefits. We include as regressors DLDEBT and TDEBT to test for these effects. DLDEBT is the change in the firm's long-term private debt load: increasing private debt, which increases monitoring and interest payments, should support greater use of tax debt. TDEBT is the start-of-year ratio of tax debt to total assets: the agency story predicts an optimal ratio of tax to private debt, ceteris paribus, and thus the higher is the current ratio of tax debt, the less desirable additional tax debt should be. 
However, essentially all of the coefficients were statistically insignificant, and their signs are inconsistent. Further, those few with statistically significant coefficients have a sign opposite that which the theory predicts. We conclude that we find no evidence in support of the agency theory explanation for underutilization. A more careful analysis of agency theory effects on financial decisions such as underutilization requires a more complete study, and is a possible topic for a subsequent study.

Due to heteroskedasticity and heterogeneity we divided the sample into four different groups. In Table 4 we report the standard error of the estimated nonlinear regression line for each group in each year. The variation is greatest in 1991 and the small firms seem to be more heterogeneous than medium and large firms. The standard deviation estimates support our view that it is important to accommodate substantial heterogeneity, even after normalizing the variables with a size measure.

Our estimation equations take the form of a doubly censored Tobit model. In Table 4 we report the proportion of observations censored in each group. These proportions can be combined with the Tobit coefficient estimates to estimate marginal effects.

To check the robustness of our results, we estimated three variants: (1) We collapsed the observations into a single sample (per year), and obtained the same qualitative results (but a strong rejection of the hypothesis that the coefficients should be strictly the same across groups); (2) We collapsed the observations into a single sample (per year) but allowed the intercept to differ across size groups (size dummies), with the same qualitative results; (3) We estimated industry dummies, but their estimated coefficients were all statistically insignificant.

\section{Concluding Observations}

Our results add strong new evidence that corporations undertake tax planning in a more complex environment than most of the theoretical literature assumes. In the typical model, corporations maximize a value function, which is decreasing in the firm's after tax-cost of capital (see, for instance, Auerbach (1983), Biørn (1989) or Sinn (1987) for a survey of the literature). The cost of capital is decreasing in the firm's tax depreciation rate. Therefore the standard implication is that firms should deduct all permitted depreciation. We find that this is not always true. Instead, tax depreciation can be a strategic and endogenous variable for corporations. The primary reasons for the practice of underutilizing tax deductions seem to be:

- Depreciation deductions compete with potentially expiring tax loss carryforwards: firms postpone depreciation in order to recover their loss deductions.

- Keeping separate tax and book accounts imposes costs. Costs can be avoided if a firm equalizes tax and book depreciation by underutilizing tax depreciation. This type of behavior is frequent among small firms. ${ }^{45}$

- Firms use (costly) windowdressing on their financial accounts when they have low net income.

We investigated two other major hypotheses: that uniform reporting requirements may impose a dividend constraint that can be loosened by depreciation underutilization; and 
that firms may at the margin prefer to increase higher-interest private debt rather than zerointerest tax debt to obtain benefits from bank monitoring. We tested several predictions of these hypotheses and found little evidence to support them as important determinants of the observed underutilization.

In recent work by Forsling (1998a, 1998b), prepared after we distributed the first version of this study, he has focused on underutilization by Swedish firms. He limits his sample to firms in tax-paying status, and therefore is silent on the role of tax loss carryforwards, which we find to be extremely important. His measurement of windowdressing effects is limited to efforts to smooth reported earnings. He confirms some of our results, including the effects of administrative costs and low profitability.

Our research could be extended usefully in several directions. First, we do not provide a direct estimate of the accounting costs. Second, it is a difficult task to measure a firm's desired dividend distribution and therefore the point where it is effectively constrained. Third, it is difficult to measure directly monitoring costs from tax and financial data. Further research may demonstrate that these motivations also induce underutilization of allowable tax deductions.

\section{Appendix A. The Norwegian Corporate Tax System}

\section{A.1. Before 1992}

The corporate tax system in Norway is quite similar to those found in most OECD countries, with a few important differences. The municipal tax rate is quite high, and before 1992 it was paid on a base somewhat different from the national tax. A substantial fraction of pre-tax earnings could be allocated to various tax-deferred accounts. And, as mentioned above, different from some but not all OECD countries, before 1992 there was uniform reporting, which required reconciliation between the tax and the accounting measures. We will describe some important details of the tax calculation.

The definition of accounting profit after tax is

$$
\Pi-d^{\mathrm{B}}-r B-\left(d^{\mathrm{T}}-d^{\mathrm{B}}\right)-F-T
$$

where $\Pi$ is operating profits, $d^{\mathrm{B}}$ is book depreciation, $d^{\mathrm{T}}$ is tax depreciation (and thus $\left(d^{\mathrm{T}}-d^{\mathrm{B}}\right)$ is accelerated depreciation), $F$ is fund allocations, $T$ is corporate tax and $r B$ is net interest cost where $r$ is the interest rate and $B$ is the net debt. The amount of accelerated depreciation, $\left(d^{\mathrm{T}}-d^{\mathrm{B}}\right)$, can be either positive and negative. When the corporation has positive net investments accelerated depreciation will usually be positive, when net investments are negative accelerated depreciation will usually be negative. Only the declining balance method is used for tax depreciation on physical assets. This method is geometric: a given percentage of the remaining undepreciated value of the asset is deductible in each year. Book depreciation, $d^{\mathrm{B}}$, which can be either linear or geometric, is intended to approximate economic depreciation, and may differ from tax depreciation.

The most important tax deferred fund allocation, $F$, was the so-called consolidation fund. Each year a corporation could allocate 23 percent of the pre-tax profit into this fund. There were no requirement to reverse these fund allocations, which meant that the 
corporation could defer taxes to infinity. The consolidation fund allocation can be defined as

$$
F=\varphi \max \left(0, \Pi-d^{\mathrm{B}}-r B-\left(d^{\mathrm{T}}-d^{\mathrm{B}}\right)-\Psi\right)
$$

where $\varphi$ is the consolidation fund allocation rate, 23 percent in 1991, and $\Psi$ denotes tax loss carryforwards. We see from (A.2) that a corporation with a negative tax base after loss carryforwards could not allocate to the consolidation fund. For simplicity we will assume, however, that the tax base after loss carryforwards is positive.

Before 1992 corporations paid a municipal tax of 23 percent, and a national tax of 27.8 percent, for a total of 50.8 percent. The tax bases were different: dividends were deducted only for the national tax. We let $\eta$ be the municipal tax rate and $\kappa$ be the national tax rate, to write the total tax as

$$
\begin{aligned}
T= & \eta\left(\Pi-d^{\mathrm{B}}-r B-\left(d^{\mathrm{T}}-d^{\mathrm{B}}\right)-F-\Psi\right) \\
& +\kappa\left(\Pi-d^{\mathrm{B}}-r B-\left(d^{\mathrm{T}}-d^{\mathrm{B}}\right)-F-\Psi-\max \left[0, D^{*}\right]\right)
\end{aligned}
$$

where

$$
D^{*}=\min \left[D, \Pi-d^{\mathrm{B}}-r B-\left(d^{\mathrm{T}}-d^{\mathrm{B}}\right)-F-\Psi\right]
$$

where $D$ is dividends. Dividends are deductible in the national tax base only to the extent of positive current profit after loss carryforwards. ${ }^{46}$

Norwegian corporate tax law permits a corporation to pay dividends out of current profit plus free equity (accumulated retained earnings). Therefore as an accounting definition we have

$$
\Pi-d^{\mathrm{B}}-r B-\left(d^{\mathrm{T}}-d^{\mathrm{B}}\right)-F-T+\Omega=D+R+(\Delta \Omega+\Omega)
$$

where $R$ is the allocation to the reserve fund, and $\Omega$ is the firm's free equity. ${ }^{47}$ The residual, $\Delta \Omega$, can be positive or negative depending on the current profit.

One exogenous constraint on dividends is that under certain circumstances, some of the current profit must be allocated to the so-called reserve fund $(R)$. The reserve fund is equity that must be retained to protect the creditors: it has no tax consequences but it cannot be used to finance dividends. ${ }^{48}$ The reserve fund requirement is most often binding for new corporations, corporations that use debt as their primary financing source, and corporations that do not have enough return on their investment to build up the reserve fund (these will, of course, disappear in the long run).

If we use (A.2) and (A.3) to substitute for $T$ and $F$ in (A.5), assume that current profit after loss carryforwards is positive, ${ }^{49}$ and then solve for $d^{\mathrm{T}}$ and add the maximum allowable tax depreciation $d^{\max }$ on both sides to find the amount of underutilization we get:

$$
\begin{gathered}
d^{\max }-d \equiv d^{\max }+r B-\Pi-\frac{1}{(1-\varphi)(1-u)}[(\varphi+(1-\varphi) u) \Psi-D(1-\kappa) \\
-(\Delta \Omega+\Omega)-R]
\end{gathered}
$$

where $u=\eta+\kappa \cdot .^{50}$ 


\section{A.2. After 1992}

The 1992 tax reform changed the corporate tax system radically. The corporate tax rate (combined municipal and national) was reduced from 50.8 percent to 28 percent. This reduction was offset by an increase in the tax base. Allocations to tax-exempt funds (e.g., the consolidation fund) were abolished and tax depreciation rates were decreased. If a corporation had owners who worked in the corporation (active owners) and who collectively controlled more than $2 / 3$ of the shares (or dividends), the corporation had to pay an additional tax, called personal tax, on corporate profits. This tax is a function of the owners' income, but the corporation pays the tax. The accounting rules were also changed, to replace uniform reporting with separate reporting.

Before the reform the difference between tax and accounting depreciation was deducted from accounting profit, and registered as an increase in long-term debt; after the reform accounting profit is only reduced by the tax value of the difference. That is, the deferred tax due to accelerated depreciation is deducted from current profit, which cancels out the effect of tax depreciation on the dividend constraint. To see this, we can write the accounting profit after the tax reform as

$$
\Pi-d^{\mathrm{B}}-r B-S+\Omega \equiv D+R+(\Delta \Omega+\Omega)
$$

where $S$ is the tax cost. Equation (A.7) tells us that current profit after tax plus free equity can be used to pay dividends, increase the reserve fund or increase owners' equity. The tax cost is the sum of the currently payable tax, $T$, and the deferred (postponed) tax, $P$, i.e. $S=T+P$. A simplified corporate tax function for the payable tax can be written as

$$
T=\tau\left(\Pi-d^{\mathrm{T}}-r B-\Psi\right)+\tau_{\mathrm{w}}\left(\Pi-d^{\mathrm{T}}-\rho K-W\right)
$$

where $\tau$ is the corporate tax rate and $\tau_{\mathrm{W}}$ is the personal tax rate. The tax base for the personal tax is operating profits minus depreciation, an imputed capital return $(\rho K)$ and a wage deduction. ${ }^{51}$ The imputed capital return is calculated as a fraction of the corporation's tangible assets (16 percent in 1992). Only the first term on the right hand side applies when the corporation is not obliged to pay personal tax.

The deferred tax can be written as

$$
P=\tau\left(d^{\mathrm{T}}-d^{\mathrm{B}}\right)
$$

which is simplified because assets other than depreciable capital will contribute to $P$. These other deferrals have no effect on our analysis, however. If we substitute for $T$ and $P$ in (A. 7) we get

$$
\begin{aligned}
& \left(1-\tau-\tau_{\mathrm{w}}\right) \Pi-(1-\tau)\left(r B+d^{\mathrm{B}}\right)+\tau_{\mathrm{w}}\left(d^{\mathrm{T}}+\rho K+W\right)+\tau \Psi+\Omega \\
& \quad \equiv D+R(\Delta \Omega+\Omega) .
\end{aligned}
$$

For $\tau_{\mathrm{w}}=0$, equation (A.10) will be reduced to:

$$
(1-\tau)\left(\Pi-d^{\mathrm{B}}-r B\right)+\tau \Psi+\Omega \equiv D+R(\Delta \Omega+\Omega) .
$$




\section{Appendix B. The Asymmetry Between Tax Depreciation and Loss Carryforwards}

It may be useful to discuss optimal strategies in the use of tax depreciation in the Norwegian tax system. If the corporate tax system consists of a constant tax rate in an infinite time horizon and the tax system is approximately symmetric i.e. losses can be carried forward, the optimal strategy is to minimize taxes every year. Even if a corporation has a negative operating result the best strategy is to minimize (negative) taxes through a maximal use of tax depreciation. The reason for this is that there is an asymmetry between tax depreciation and loss carryforwards. A loss carryforward can be increased through the use of tax depreciation, and deducted from the result in the next period. On the other hand, if a corporation does not utilize all possible tax depreciation one year, the corporation cannot claim more tax depreciation than the maximal rate multiplied with the depreciation base. To see this clearly we can illustrate this point with some equations.

Consider a corporation tax base in two periods. We assume that the tax rate is equal in both periods and linear. Let the corporation have a profit before tax depreciation equal to $\Pi_{1}$ the first period, further we assume that the depreciation base is $K$ with a depreciation on $\rho_{\mathrm{m}} K$ first period if the corporation uses the maximum rate. If the corporation uses a lower rate the depreciation is just $\rho K$. The tax base after the tax deprecation in these two cases are

$$
N_{1 \mathrm{~m}}=\Pi_{1}-\rho_{\mathrm{m}} K<0, \quad N_{1}=\Pi_{1}-\rho K=0
$$

where $N_{1 \mathrm{~m}}$ is the tax base when full tax depreciation is used and $N_{1}$ is the tax base with a lower depreciation. We have assumed, in making the example interesting, that use of full tax depreciation and the lower rate $\rho$ both gives zero tax in period 1. In period 2 we assume that the tax base before tax depreciation is sufficiently large to cover maximal tax depreciation. The corporation can carryforward loss to the second period. Thus, the tax base in period 2 given full tax depreciation in period 1 becomes

$$
N_{2 \mathrm{~m}}=\Pi_{2}+N_{1 \mathrm{~m}}-\rho_{\mathrm{m}}\left(1-\rho_{\mathrm{m}}\right) K .
$$

The tax base in period 2 given that the corporation used a lower depreciation rate in period 1 generally becomes

$$
N_{2}=\Pi_{2}+N_{1}-\rho_{\mathrm{m}}(1-\rho) K .
$$

We notice that there is no difference in the tax payment in period 1 . The difference between the tax bases in period 2 is

$$
N_{2}-N_{2 \mathrm{~m}}=K\left(\rho_{\mathrm{m}}-\rho\right)\left(1-\rho_{\mathrm{m}}\right)>0
$$

which is clearly positive. This means that the tax payment in period 2 is higher if the corporation uses a tax depreciation rate lower than $\rho_{\mathrm{m}}$ in the first period, even if the tax payment in the first period is the same (zero in our example). This effect is due to the asymmetric treatment of tax depreciation and loss carryforwards. Our example will exaggerate the difference between the to strategies compared to the Norwegian tax system, because we have implicitly assumed that the corporation can carry the losses forward with interest. This is 
not true in the Norwegian tax system, but as we see from equation (B.4), a discount rate cannot change our result.

\section{Appendix C. Construction of Underutilization Data}

The underutilization of tax depreciation allowances is calculated as maximum depreciation minus actually claimed depreciation. Every corporation has to fill in a tax depreciation form for every asset it owns. Every type of asset has a certain maximum percentage of depreciation that allows us to find the maximal depreciation for every single corporation within each year. The actually claimed depreciation is given on the form. It is then quite easy to calculate the difference between maximum and actual depreciation. In 1991, there were twelve different types of asset groups with different maximum allowed depreciation rates. In two of the asset groups there is not a unique maximum depreciation rate. Some of the assets in these groups have in general a maximum depreciation rate of $\rho$, while other have a maximum depreciation rate of $\rho / 2$. This makes it difficult to know the maximum rate for these assets. We have controlled for this in using the low rate if the corporation has used the low rate, and using the high rate if the corporation has used a rate higher rate than the low rate. This solution is not perfect, but is the best we can achieve given the data, and it implies that we do not exaggerate the underutilization.

Some corporations can both have negative and positive depreciation bases within one asset group. Unfortunately the asset forms are aggregated within every asset group, and the depreciation base we observe is therefore not necessarily the correct base, in fact we can in many cases observe negative bases and positive depreciation. We have, however, been able to control for this because we have the sum of the negative bases within every asset group for every corporation, but the uncertainty is greater in these cases.

The maximum and actual depreciation are calculated precisely as follows:

maximum depreciation $=($ observed base-sum of negative bases $) \cdot$ max. depr. rate, actual depreciation $=$ observed depreciation.

Recall, a firm can keep separate books even if it must report its accounts on a uniform basis to the tax authorities. See note 22 .

\section{Acknowledgments}

The first version of this paper was written while Karl Ove Aarbu was visiting the School of Public Policy, University of Michigan. Comments from Erik Ekman, Gunnar Forsling, Frode Johansen, Diderik Lund, Jan Södersten, Alan Auerbach, Douglas Shackelford, Roger Gordon, and seminar participants at the Uppsala University Public Finance seminar, the Norwegian meeting for Economists at University of Oslo, the NBER Public Finance Summer Institute 1997, Statistics Norway's Thursday Workshops, and the University of Michigan Public Finance Workshop are highly appreciated. We appreciate comments from John Dagsvik on the econometrics and Gry Bjerk Aarbu for advice on the administrative costs of the tax reporting system. We will also like to thank Per Morten Holt, Sissel Fjeld and Jan Stensrud for helping us with the data. We gratefully acknowledge financial support 
from Norwegian Research Council (grant 106173/510), and from U.S. National Science Foundation grant SES-9122240.

\section{Notes}

1. It may seem odd that the evidence for underutilization thus far comes primarily from Nordic countries. We do not think this is because Nordic tax accountants are too cold to do rational tax planning. The explanation may be no more sinister than the design of the tax forms: only in some countries do firms report both the allowable and the utilized depreciation on their tax return, so the researcher can directly observe discrepancies. In addition, corporate tax returns in most countries are usually not available for research.

2. This behavior may seem especially odd to readers from countries in which tax depreciation deductions are mandatory. However, in many countries such deductions are discretionary, creating an opportunity for firms to manipulate their financial structure through underutilization. In some countries, such as the U.S., tax depreciation is semi-mandatory: a firm can report less than the statutory depreciation if it desires, perhaps for some of the reasons discussed in this paper, but the tax basis of the asset is calculated as if the full amount of statutory depreciation was claimed, and thus the foregone deductions may not later be recovered, making the opportunity cost of such underutilization much higher than in countries where deductions can be deferred. We thank Cathy Netz for professional tax advice on this detail of the U. S. tax code.

3. The scholarly finance community has long puzzled over whether tax policy has any effect on corporate financial policy. For example, Stewart Myers (1984) wrote in his Presidential Address to the American Finance Association, "I know of no study clearly demonstrating that a firm's tax status has predictable, material effects on its debt policy. I think the wait for such a study will be protracted." MacKie-Mason (1990) provided evidence that a firm's marginal tax rate did affect its choice between debt and equity financing. Shum (1996) finds similar evidence for a sample of Canadian firms. Shum mentions the fact that depreciation is sometimes underutilized in Canada, and suggests the hypothesis that underutilization is to enable recovery of tax loss carryforwards that might otherwise expire, which we test below. Shum does not test this hypothesis nor treat underutilization in her empirical work. MacKie-Mason and Gordon (1997) show that tax treatment has material effects on the choice of legal form of organization. The present paper continues this line of research by asking why firms decline to fully utilize an obvious form of tax-subsidized, zero-interest debt (i.e., depreciation deductions).

4. The implication of the uniform reporting constraint on dividends was first explored by Boadway (1980) and further extended by Kanniainen and Södersten (1994). They, Sinn (1987), and Cummins, Harris and Hassett (1995) catalogue the use of uniform reporting by OECD-countries; roughly the divide is between "AngloSaxon" (separate reporting) and other countries.

5. Cummins, Harris and Hassett (1995) provide a more general description of the differences between uniform and separate accounting rules used in various countries. We focus solely on the Norwegian case.

6. See the appendices. More details are reported in an appendix available at http: /www-personal . umich . edu/ jmm/research.html.

7. The most important fund $(F)$ is the consolidation fund; each year a corporation could allocate 23 percent of its pre-tax profit into this fund. There were no requirement to reverse these fund allocations, which meant that the corporation could defer taxes to infinity. The reserve fund is equity that must be retained to protect the creditors: it has no tax consequences but it cannot be used to finance dividends. See the appendix for additional details on both funds.

8. In most countries firms are allowed to use different depreciation schemes for tax and accounting purposes. One justification is presented by the Technical Committee on Business Taxation (1997): "Capital cost allowances permitted for income tax purposes should be based on a uniform and simple system, applicable to all taxpayers, and not dependent on various accounting approaches to depreciation used by individual businesses" (p. 4.7). In addition, tax depreciation rates are often accelerated to subsidize capital investment.

9. See, for example, Sørensen (1994) or Kanniainen and Södersten (1995) for a discussion of different reporting conventions. Cummins, Hassett and Harris (1995) investigate the impact of uniform reporting on firm investment, but do not investigate underutilization of depreciation allowances. 
10. Additional details of the reform relevant to our measurement of variables are described in the appendix referenced in note 6 .

11. To keep the presentation simple, we again assumed that the firm's dividends are sufficiently small that it is permitted to deduct the full amount from the pre-reform national tax base. We have also assumed that the corporation does not have active owners sufficiently large to incur the personal tax. These complications would change the algebraic expressions but not the conclusion that the dividend constraint could move in either direction after the reform.

12. We do not pursue one possible explanation: firms may wish to delay their depreciation deductions if they expect tax rates to increase soon and by enough to outweigh the interest cost of delay and the cost of the uncertainty. This seems unlikely for the Nordic countries, since during this period they reformed their corporate tax systems to lower tax rates. Further, these reforms were among the latest in the OECD-countries (Whalley, 1990). Due to the openness of the Nordic economies, there is strong pressure to keep corporate tax rates down near the levels of their trading partners, so there is no reason to think corporations expected tax rates to increase any time soon. In any case, we have no data to identify a test of this hypothesis.

13. Since the reform small firms have been given significant latitude to equalize tax and book depreciation to reduce the costs of maintaining two sets of accounts.

14. We thank Alan Auerbach for urging us to think more carefully about this phenomenon.

15. Loss carry backs are not allowed in Norway. However, even if they were allowed, our reasoning does not change. A firm which has losses that are about to expire, would have carried them back before if it had positive profits in the past. It cannot be optimal to wait to reduce the taxes, less taxes today is better than less taxes tomorrow, due to the discount factor.

16. We show this more formally in the available appendix; see note 6 .

17. Following the Norwegian rule we switch to immediate write-off when the book value reaches $15,000 \mathrm{NOK}$.

18. When a firm use a declining balance scheme the tax depreciation deductions falls over time, which means that the firm can use a larger and larger fraction of TLCF (if they have not expired due to the ten years rule).

19. See, e.g., Matsunaga, Shevlin and Shores (1992), Collins, Shackelford and Wahlen (1995), Hand (1989), and Beatty, Chamberlain and Magliolo (1995).

20. A recent article in a financial industry trade journal clearly states the prevalence of windowdressing: "Dressing up earnings has never been more fashionable ... The gap between Wall Street's numbers and bottom-line reality is widening, observers say, as companies increasingly lump all manner of costs into one-time charges that don't count against operating earnings. Driving this trend are companies anxious to gussy up their falling profits and sell-side analysts who are all too willing to help out. The result is that quarterly reports, as poor as they are, often give investors an unduly rosy view of how companies are faring." Lahart (2001).

21. We discuss transaction costs below and point to a case in which tax depreciation would have an effect on book income, even after the tax reform.

22. Recall that while uniform reporting requires an adjustment entry to reconcile the difference between book and tax depreciation, it is permissible to record them differently in financial and tax accounts. See the text accompanying note 9 .

23. Tax administration costs probably did not change much following the tax reform. Before, the corporation had to track the accumulated difference between tax and book values; after, it has to track the same difference times the tax rate.

24. Earlier studies have documented the significance of business tax compliance costs. See, e.g., Blumenthal and Slemrod (1996a, b).

25. To avoid problems with round-off and other small arithmetic errors, we actually define DIVC $=1$ if the constraint equality is satisfied within 2000 NOK (\$US 300). The actual point where DIVC shifts to one is based on empirical investigation for firms with dividends near the maximum allowable dividends. From graphs (available from the authors on request) we find that firms cluster below this point, while firms over this trigger point are evenly spread.

26. Norwegian tax rules limit loss carryforwards to ten years.

27. TAXP is set to 1 when a firm would pay current taxes if it fully utilized its allowable depreciation allowances, to avoid simultaneity bias.

28. A firm can affect current tax losses through various instruments, including the amount of depreciation 
claimed, so current tax losses and underutilization are jointly determined. However, tax losses carried forward we predetermined with respect to current depreciation decisions, so we consider only one direction of causality.

29. This hypothesis has an implication for empirical methods in the study of taxes and capital structure. Since MacKie-Mason (1990) many authors have used TLCF as a proxy for tax exhaustion, which indicates that a firm faces a lower effective marginal tax rate on interest deductions. Our hypothesis suggests that TLCF should be supplemented by underutilization of depreciation allowances (in countries where that is permissible) because choosing to forego depreciation deductions indicates an even lower expected marginal tax rate (greater expectation of remaining tax exhausted).

30. OLDTLCF is calculated as TLCF $10+0.75 \mathrm{TLCF}_{9}$, where the subscript indicates the age of the TLCF. The 1988 data file contains no loss carryforward historical data, so we use only accumulated loss carryforwards as an explanatory variable for this year.

31. We define DIVP using full utilization because actual utilization is endogenous.

32. Market equity to book debt is not included in our measure of ZPROB because it cannot be observed for most of the firms. However, the exclusion of the market equity variable will not decrease the importance of the other financial variables.

33. About 5-10 observations have higher values for ZPROB each year. We could instead drop these observations from our sample, however the observations seem to be normal in all other respects so we keep them in the sample.

34. There are variables other than depreciation that can cause a difference between tax and accounting values, and thus a non-zero tax debt. It is possible that these could exactly offset depreciation differences, so that zero tax debt would not indicate depreciation equalization. We assume that this remote possibility does not occur in our sample.

35. We are grateful to the editor for suggesting this consideration.

36. It is possible that the disturbance for our dependent variable and the disturbances for one or more of our lagged explanatory variables have a common autoregressive error component that would induce simultaneity even after lagging. We do not have instruments available to test this possibility.

37. We have tried several size-measures; both total assets and different definitions of sales. The results are not sensitive to the choice of the size-measure.

38. It may be other ways to care of the variability, for instance with use of dummy variables both for slope and intercept or a model with random coefficients. The division of the sample after SIZE, is however, simple and the results should be easier to interpret.

39. There will always be some minor rounding errors between our calculation of maximal tax depreciation and the maximal tax depreciation given on the tax form, because the Norwegian tax authorities round off to nearest hundred or thousand (the practice can vary across local tax authorities). From a graphical analysis we find that observations are clustered below underutilization of 200 NOK (\$US 30), which we treat as the censoring point.

40. We used the PROC LIFEREG procedure in SAS

41. The sampling was random within strata, with strata weights chosen so that statistics would gross up to represent the entire Norwegian economy.

42. We are grateful to an anonymous referee suggesting the former selection.

43. In 1988 we find that the average fraction of dividends paid out of possible dividends (for dividend paying firms) ranges from 0.11 (group 1) to around 0.33 for medium and large corporations. In 1991 the fraction is 0.1 independent of group, from 0.30 to 0.75 in 1992 and a range from 0.18 to 0.44 in 1993. Similar low ratios for actual dividends relative to permissible dividends are reported by Bøhren et al. (1997, Table 7A) for all publicly traded firms in Norway.

44. Tobit estimates are not marginal estimates, i.e., they do not directly yield the local derivative of underutilization with respect to the explanatory variables. Following Greene (1990, p. 730), we can find a rough marginal estimate from multiplying the Tobit estimates by the proportion of uncensored observations. These proportions are given in Table 4.

45. Recall, a firm can keep separate books even if it must report its accounts on a uniform basis to the tax authorities. See note 22 . 
46. Firms are also allowed to pay dividends out of their accumulated retained earnings, but these are not tax deductible. Equation (A.3) is a simplification of the Norwegian corporate tax function. There are several other deductions, but for our theoretical analysis these can be omitted without any loss of generality.

47. We have ignored one additional complication that does not affect the qualitative implications. For the purpose of paying dividends, a firm can add the accumulated consolidation fund net of the value of taxes deferred to its free equity.

48. The firm must allocate 10 percent of current year profit after tax to the reserve fund if the accumulated reserve fund is: (i) less then 20 percent of the book share value, or (ii) the reserve fund plus revaluation fund plus book share value (we call this amount $X$ ) is less than total debt. (The revaluation fund is where the firm accumulates periodic book value adjustments due to significant changes in the market value for assets.) In addition, if the corporation chooses to pay more dividends than 10 percent of $X$, it must also allocate the same amount to the reserve fund as the difference between dividend paid out and 10 percent of $X$.

49. This assumption is for expository ease; the qualitative results do not depend on it.

50. To calculate the amount of the dividend that is deductible from the national tax base (see equation (3)), we have assumed that the dividend itself is less than current pre-tax net income net of loss carryforwards (and thus is fully deductible, and the coefficient on $D$ becomes $1[(1-\varphi)(1-u)]$. If the net income measure is negative, no dividend is deductible, and the coefficient on $D$ becomes $1[(1-\varphi)(1-\eta)]$. Obviously, the qualitative relationship between underutilization of tax depreciation and the payable dividend is unaffected by which of these three cases is in effect.

51. The "lønnsfradrag" or supplemental wage deduction is intended to account for a return to managerial human capital. It is calculated as a percentage of the difference between the firm's total wages and the wages of the active owners. The current percentage is 20 percent

\section{References}

Aarbu, K. O. (1994). "Utnyttelse av Avskrivninger og Avsetninger i Norske Foretak." ("Utilization of Tax Depreciation and Profit Funds in Norwegian Corporations.") Økonomiske Analyser 4(94), 35-41, Statistics Norway.

Altman, E. I. (1968). "Financial Ratios, Discriminant Analysis, and the Prediction of Corporate Bankruptcy." Journal of Finance 23, 589-609.

Altshuler, R. and A. J. Auerbach. (1990). "The Significance of Tax Law Asymmetries: An Empirical Investigation." Quarterly Journal of Economics 105, 61-86.

Askildsen, J. E. and E. Fjærli. (1989)."Bedrifters Skattetilpasning og Utnyttelse av Avskrivnings-Ordninger." ("Adaptation to the Tax System and Tax Depreciation in Norwegian Corporations.") Appendix 3, Norges Offentlige Utredninger (NOU) 1989: 14, Oslo.

Auerbach, A. J. (1983). "Taxation, Corporate Financial Policy and the Cost of Capital." Journal of Economic Literature 21, 905-940.

Beatty, A., S. L. Chamberlain and J. Magliolo. (1995). "Managing Financial Reports of Commercial Banks: The Influence of Taxes, Regulatory Capital, and Earnings." Journal of Accounting Research 33(2), 231-261.

Biørn, E. (1989). Taxation, Technology and the User Cost of Capital. Amsterdam: North-Holland.

Blumenthal, M. and J. Slemrod. (1996a). "The Income Tax Compliance Cost of Big Business.” Public Finance Quarterly 24(4): 411-438.

Blumenthal, M. and J. Slemrod. (1996b). "The Compliance Cost of Taxing Foreign-Source Income: Its Magnitude, Determinants, and Policy Implications.” In J. Slemrod (ed.), The Taxation of Multinational Corporations. Kluwer Academic Publishers, 1996.

Boadway, R. (1980). "Corporate Taxation and Investment: A Synthesis of Neoclassical Theory." Canadian Journal of Economics 13, 250-267.

Bøhren, O., B. E. Eckbo, D. Michalsen and D. Smith. (1997). "Corporate Dividend Policy in Norway.” Research Report No. 1/1997, Department of Business Economics, Handelshøyskolen BI, Oslo, Norway.

Collins, J. H., D. A. Shackelford and J. M. Wahlen. (1995). "Bank Differences in the Coordination of Regulatory

Capital, Earnings, and Taxes.” Journal of Accounting Research 33(2), 263-291.

Cummins, J. G., T. S. Harris and K. A. Hassett. (1995). "Accounting Standards, Information Flow, and Firm 
Investment Behavior.” In M. Feldstein, J. Hines and R. G. Hubbard (eds.), The Effects of Taxation on Multinational Corporations. NBER.

Erstad, T. (1990). "Inntekts- og formuesunders $\varnothing$ kelsen for etterskuddspliktige 1988." ("The Income and Wealth Survey for Corporations 1988.”) Interne notater 90/25, Statistics Norway.

Forsling, G. (1998a). "Utilization of Tax Allowances." Finnish Economic Papers 11(2), 96-109.

Forsling, G. (1998b). Economic Studies 37 (Ph.D. Dissertation), Department of Economics, University of Uppsala, Sweden.

Greene, W. H. (1990). Econometric Analysis. New York: Macmillan.

Hand, J. R. M. (1989). "Did Firms Undertake Debt-Equity Swaps for an Accounting Paper Profit or True Financial Gain?” Accounting Review 64(4), 587-623.

Jensen, M. C. and W. H. Meckling. (1976). "Theory of the Firm: Managerial Behavior, Agency Costs and Ownership Structure.” Journal of Financial Economics 3(4), 305-360.

Jensen, M. C. (1986). "Agency Costs of Free Cash Flow, Corporate Finance, and Takeovers." The American Economic Review 76(2), 323-329.

Kanniainen, V. and J. Södersten. (1994). "Cost of Monitoring and Corporate Taxation.” Journal of Public Economics 55, 307-321.

Kanniainen, V. and J. Södersten. (1995). "The Importance of Reporting Conventions for the Theory of Corporate Taxation.” Journal of Public Economics 57, 417-430.

Lahart, J. (2001). "Reality Gap Widens on Wall Street as Charges Grow." The Street.com, 17 July. Available at http://www. thestreet.com/markets/justinlahart/1493306.html (accessed 31 July 2001).

MacKie-Mason, J. K. (1990). "Do Taxes Affect Corporate Financing Decisions?” Journal of Finance 45(5), 1471-1493.

MacKie-Mason, J. K. and R. H. Gordon. (1997). "How Much do Taxes Discourage Incorporation.” Journal of Finance, June.

Maddala, G. S. (1983). Limited-Dependent and Qualitative Variables in Econometrics. Cambridge: Cambridge University Press.

Matsunaga, S., T. Shevlin and D. Shores. (1992). "Disqualifying Dispositions of Incentive Stock Options: Tax Benefits versus Financial Reporting Costs.” Journal of Accounting Research 30, 37-68.

Myers, S. C. (1984). "The Capital Structure Puzzle." Journal of Finance 39(3), 575-592.

Myers, S. C. and N. S. Majluf. (1984). "Corporate financing and investment decisions when firms have information that investors do not have." Journal of Financial Economics 5, 147-175.

Nygaardsseter, S., A. Sorbraten, P. E. Gjedtjernet, W. Nordhus and P. M. Holt. (1995). "Inntekts- og formuesunders $\varnothing$ kelsen for aksjeselskaper og andre etterskuddspliktige 1991 og 1992." ("The Income and Wealth Survey for Corporations 1991 and 1992.”) Notater 95/9, Statistics Norway.

Shum, P. M. (1996). “Taxes and Corporate Debt Policy in Canada: An Empirical Investigation.” Canadian Journal of Economics 29(3), 556-572.

Sinn, H. W. (1987). Capital Income Taxation and Resource Allocation. Amsterdam: North-Holland.

Sørensen, P. B. (1994). "Some Old and New Issues in the Theory of Corporate Income Taxation." Finanzarchiv 51(4), 425-456.

Stiglitz, J. and A. Weiss. (1981). "Credit Rationing in Markets with Imperfect Information.” American Economic Review 71(3), 393-410.

Technical Committee on Business Taxation. (1997). "Report of the Technical Committee.” Department of Finance (Ottawa, Canada). Available at http://www.fin.gc.ca/taxstudy/tsrep_e.pdf (accessed 4 July 2001).

Whalley, J. (1990). “Foreign Responses to U.S. Tax Reform.” In J. Slemrod (ed.), Do Taxes Matter? Cambridge, MA: MIT Press. 